\title{
BIBLIOGRÁFIA
}

\section{A magyar nyomda-, könyv-, sajtó- és könyvtártörténeti szakirodalom $2017^{*}$-ben}

\section{Rövidítések}

\begin{tabular}{|c|c|}
\hline ItK & $=$ Irodalomtörténeti Közlemények \\
\hline KF & = Könyvtári Figyelő \\
\hline KKK & = Könyv, Könyvtár, Könyvtáros \\
\hline $\mathrm{KN}$ & $=$ Könyv és Nevelés \\
\hline MG & $=$ Magyar Grafika \\
\hline MKsz & = Magyar Könyvszemle \\
\hline MTud & = Magyar Tudomány \\
\hline MVízjel & = Magyar Vízjel \\
\hline MüvtörtÉrt & = Müvészettörténeti Értesítő \\
\hline Ex oriente amicitia... & $\begin{array}{l}=\text { Ex oriente amicitia. Mélanges offerts à Frédéric Barbier à } \\
\text { l'occasion de son 65e anniversaire / ed. par Claire MADL, } \\
\text { István MoNOK. Bp.: MTA KIK, 2017. } 420 \text { p. ill (L'Europe en } \\
\text { réseaux; 7.). }\end{array}$ \\
\hline Fordítás, tolmácsolás, értelmezés.. & $\begin{array}{l}=\text { Fordítás, tolmácsolás, értelmezés / szerk. Mikusi Balázs, Ró- } \\
\text { zSAFALVI Zsuzsanna, SIRATó Ildikó. Bp.: Bibl. Nationalis Hun- } \\
\text { gariae-Gondolat, 2017. } 263 \text { p. ill. (Bibliotheca scientiae \& } \\
\text { artis; 9.) }\end{array}$ \\
\hline A home of arts and muses... & $\begin{array}{l}\text { A home of arts and muses. The library of King Matthias Cor- } \\
\text { vinus / ed. by Edina Zsupán. Bp.: Bibl. Nationalis Hungariae, } \\
\text { 2017. } 212 \text { p. ill. (De Bibliotheca Corviniana). (Supplemen- } \\
\text { tum Corvinianum; 4.) }\end{array}$ \\
\hline Husz János és a huszitizmus... & $\begin{aligned} \text { = Husz János és a huszitizmus hatása a magyarországi mủvelő- } \\
\text { désben / szerk. KovÁcs Eszter, MészÁRos Andor. Esztergom: } \\
\text { Szent Adalbert Közép- és Kelet-Európa Kutatásokért Alapít- } \\
\text { vány; Bp.: ELTE BTK Müvelődéstörténeti Tanszék-ELTE } \\
\text { BTK Vallástudományi Központ-OSZK, 2017. } 179 \text { p. }\end{aligned}$ \\
\hline Lelkiség és & $\begin{aligned}= & \text { Lelkiség és irodalom. Tanulmányok Szelestei N. László tisz- } \\
& \text { teletére / szerk. BAJÁKI Rita et al. Bp.: MTA-PPKE Barokk }\end{aligned}$ \\
\hline
\end{tabular}

* 2015-ös és 2016-os impresszummal megjelent publikációk pótlásával 
Librum evolvo...

A reformáció könyvespolca...

A Telekiek és a kultúra...

Térképtörténeti Közlemények...

University and universality...
Irod. és Lelkiség Kutcsop., 2017. 536 p. ill. (Pázmány irodalmi mühely. Lelkiségtörténeti tanulmányok; 17.)

= KNAPP Éva: Librum evolvo. Eszme- és könyvtörténeti tanulmányok a XVI-XX. századból. Bp.: Reciti, 2017. 319 p.

= A reformáció könyvespolca. Reprezentatív kiadványok Magyarországon a reformáció korából / szerk. P. VÁsÁRHELYI Judit. Bp.: OSZK - Argumentum K., 2017. 148 p. ill. (A Magyar Könyvszemle és a MOKKA-R Egyesület füzetei; 9.)

= A Telekiek és a kultúra. A 2016. októberi marosvásárhelyi konferencia tanulmányai/ szerk. BÁNYAI Réka. Marosvásárhely: Teleki Téka Alapítvány, 2017. 338 p. ill.

= Térképtörténeti Közlemények 1.: Az Országos Széchényi Könyvtár Térképtárának évkönyve 2016. / főszerk. PÁszTI László. Bp.: OSZK, 2017., 158 p. ill.

$=$ University and universality. The place and the role of the University of Pécs in Europe from the Middle Ages to present day. International university history conference. 12-13 October 2017, Pécs. Conference volume / ed. Ágnes FischerDÁrdai, István Lengvári, Éva Schmelczer-PohÁnKa. Pécs: Univ. Libr. of Pécs and Centre for Learning, 2017. 394 p. ill. (A Pécsi Egyetemi Könyvtár kiadványai; 16.)

„Üstököst látni”...

= „Üstököst látni”. Az 1680. évi üstökös müvelődés- és tudománytörténeti emlékei / szerk. FARKAs Gábor Farkas, SzeBELÉDI Zsolt, VARGA Bernadett, Zsoldos Endre. Bp.: MTA KIK - Jaffa K., 2017. 597 p. ill. (Lichniae)

A véleménysajtótól a tömegsajtóig... = A véleménysajtótól a tömegsajtóig. Fejezetek a magyar újságírás történetéből / szerk. KLESTENITZ Tibor, PAÁL Vince. Bp.: MTA BTK, 2017. 182 p. ill. (Médiatudományi könyvek)

\section{Általános és összefoglaló munkák, elvi kérdések}

Ács Pál: Az Ige fogságában. Biblia és bibliaismeret Magyarországon a reformáció korában = Viszály és együttélés. Vallások és felekezetek a török hódoltság korában / szerk. ITTzÉs Gábor. Bp.: Universitas, 2017. 65-88.

AJKAY Alinka: „A’ Magyar Nyelvnek polgári nyelvvé emelése felől”. Kazinczy pályaművének kiadás-, kutatás- és recepciótörténete $=$ MKsz (133.) 2017. 3. 213-236.

BAKONYI Gábor: A Pannonhalmi Főapátsági Könyvtár kora újkori zoológia könyveinek vizsgálata = Állattani Közl. (102.) 2017. 1/2.3-23. ill.

A Függelékben a Pannonhalmi Főapátsági Könyvtárban található, 16-18. századi zoológiai könyvek listájával

BóDAI Dalma: Híráradat és történetírás - Buda 1686-os ostroma Christoph Boethius Kriegs-Helms című könyvsorozatában = Adsumus XV. / szerk. FARKAs Flóra, MosA Diána. Bp.: ELTE Eötvös J. Collegium, 2017. 191-202.

Egy 17. századi kompiláció, mint a híradás és információáramlás eszköze

BoRdÉ Katalin: Kner Imre és a Magyar Bibliophil Társaság = Szabolcs-Szatmár-Beregi Szle (52.) 2017. 3. 95-109. 
CséBy Géza: A keszthelyi Helikon. Gróf Festetics György szerepe a magyar müvelődéstörténetben. Zalaegerszeg: Pannon Írók Társ., 2017. 434 p. ill.

Kiadás-, könyvtár-, sajtó-, és nyomdászattörténeti adatokkal

Csorba Dávid: Néderlandikák - 17. századi kálvinista ereklyék Hollandiából = Németalföld emlékei Magyarországon. Magyar - holland kapcsolatok / szerk. BÁRÁNY Attila et al. Debrecen: Debreceni Egy. K., 2017. 89-108. ill.

Könyvészeti adatokkal

Csorba Dávid: A reformáció által megújított prédikátori megszólalás - Prédikációs kötetek elemzése, adalék kora újkori protestáns olvasmánymüveltséghez $=$ A reformáció könyvespolca... 108-116. ill.

Csorba Dávid: Kálvinista üstökösök - Kisztei Péter Üstökös csillagának világa = „Üstököst látni”... 190-212.

Könyvészeti adalékokkal

Dóве́к Ágnes: Barkóczy Ferenc szerepe Muratori müveinek és szellemiségének hazai elterjedésében = Egyház és társadalom. Válogatott tanulmányok a 2016. november 17-én az egri Eszterházy Károly Egyetemen rendezett Egyház és társadalom konferencia előadásaiból / szerk. MizerA Tamás, NAGY Andor. Eger: Líceum K., 2017. 11-22.

Könyvészeti adatokkal

DukKon Ágnes: Le cheminement dans l'Europe des XVIe et XVIIe siècles du Calendrier historical un type de publication populaire $=$ Ex oriente amicitia... 63-85. ill.

Ecsedy Judit, V.: A 18. századi nemzeti bibliográfia helyzete = MKsz (133.) 2017. 1. 115-117.

Hozzászólás Borda Lajos téziseihez. Országos Széchényi Könyvtár, 2016. március 2.

ERDÉsz Ádám: A Kner család és más történetek. Tanulmányok. Bp.: Osiris, 2017. 372 p. ill.

A kötet első fele a szerző már korábban megjelent tanulmányait tartalmazza a Kner-családról

Ex oriente amicitia. Mélanges offerts à Frédéric Barbier à l'occasion de son 65e anniversaire / ed. par Claire MADL, István MonOK. Bp.: MTA KIK, 2017. 420 p. ill (L’Europe en réseaux; 7.)

Tanulmányok Frédéric Barbier 65. születésnapjára

GAJDA Péter: Auguste de Gerando La Transylvanie et ses habitants címü művének latin és francia nyelvü forrásai $=$ Nyom-követés 2 . Tanulmánykötet. A Vajdasági Magyar Doktoranduszok és Kutatók Szervezete és a Doktoranduszok Országos Szövetsége Irodalomtudományi Osztály I. közös konferenciájának tanulmánykötete / szerk. Dомокоs Gyöngyi et al. Újvidék: Vajdasági M. Doktoranduszok és Kutatók Szervezete; Bp.: DOSZ Irodalomtudományi Oszt., 2017-. 23-36. (Doktoranduszok Országos Szövetsége Irodalomtudományi Osztály tanulmánykötet; 2.)

Auguste de Gerando olvasmánymüveltségére, felesége családjának, a Telekieknek könyvtárára vonatkozó adatokkal

GAusz Ildikó: Protestáns propagandafolyamatok a későhumanizmus korában = Acta Universitatis Szegediensis. Acta Historica. 141. 2017. 15-32.

Jacques Bongars Rerum Hungaricarum scriptores varii. Historici, geographici. (Frankfurt, 1600.) címü müvéről

Goмвos Péter: A 19. századi magyar mesegyüjtők és az irodalmi népmese. A népmese és mümese alapvető müfaji kérdéseiről = KKK (26.) 2017. 11. 46-52.

19-20. századi magyar mesegyüjtemények: a kiadványok szerkesztési elvei és olvasóközönsége

GöMÖRI György: Ifjabb Enyedi István külföldi tanulása és levele Sir Isaac Newtonhoz. = MKsz (133.) 2017. 4. 418-426. ill.

Adatok ifj. Enyedi István és Isaac Newton olvasmánymüveltségéhez. A Függelékben A. Jombert versének átirata. A vers Enyedi disputációjának utolsó oldalán olvasható 
GuITMAn Barnabás: Hit, hatalom, humanizmus. Bártfa reformációja és művelődése Leonhard Stöckel korában. Bp.: Szt. István Társ., 2017. 260 p. ill.

Könyvtörténeti adatokkal

Heltai János: A Régi Magyarországi Nyomtatványok (RMNy) tudománytörténeti helyzete. Megjegyzések a bibliográfiai egység fogalmáról = MKsz (133.) 2017. 1. 106-114.

Hozzászólás Borda Lajos téziseihez. Országos Széchényi Könyvtár, 2016. március 2.

HeLTAI János: Fejedelmi és egyházi reprezentáció kálvinista kiadványokban I. Rákóczi György korszakában Erdélyben = A reformáció könyvespolca... 97-107. ill.

HoRvÁTH József: Győr lakóinak mindennapi élete a 17. században. Győr: Dr. Kovács P. M. Kvt. és Közösségi Tér, 2017. 336 p. ill.

Könyvekröl, tulajdonosokról - könyves adatok: 178-181.(A mindennapi élet körülményei Személyes értéktárgyak - Könyvek)

IMRE Mihály: Szenci Molnár Albert, Jubileus esztendei prédikáció, Appendix de Idolo Lauretano, Oppenheim, 1618. A reformáció százéves évfordulójának ünneplése = Secularis concio euangelica, az az jubileus esztendei praedikatzo [!], mellyben az euangeliumnac ez elött száz esztendövel Isten kegyelméböl uyonnan kinyilatkoztarása [!], terjedése és megtartása örvendetes haláadással elöszámláltatic es megdiczirtetic. Németül praedikáltatott Haydelbergában ... az Sz. Lélec nevö öreg egyházban, Mindszent hónac 2. napján 1617. esztendöben Scultetus Abraham által. Bp.: Balassi - OSZK, 2017. Hasonmás kiad. 7-33. ill.

Index biblicvs, az az: az egez Szent Iras könyveinec kentsere vezerlö, mutato es indito laistroma, melly által kitsiny munkáual az egész Bibliában bé foglaltatott szent irásokat caputon és versenként az kiuáltképpen valo tudtodra szükséges tzickelekuel egybe, nagy hamarsáual meg találhadd, az abece betüinec rendi szerint / ... magyarrá ford. ... MANTSKouit Bálint által. Miskolc: Tiszáninneni Református Egyházker.; Sárospatak: Hernád, 2016. Hasonmás kiad. 164 p. + mell. (38 p.) A mellékletben P. Vásárhelyi Judit és Szabó András tanulmányával

KISS FARKAS Gábor: A katolikus peregrináció lehetöségei és következményei a 16. század közepén, 1530-1580 = Gerundium (8.) 2017. 1., Reformáció-Különszám. 51-70.

Könyvtörténeti, olvasmánytörténeti adatokkal

KNAPP Éva: Az ELTE Egyetemi Könyvtár ősnyomtatványtára = Hagyományok és kihívások V. Múlt és jövő. Országos Könyvtárszakmai Nap, 2016. / szerk. SzABó Panna, SzÉKElYnÉ TöRÖK Tünde. Bp.: ELTE Egyetemi Kvtára és Lvtára, 2017. 69-87. ill.

KNAPP Éva: Báthory István lengyel király könyvajándéka az ELTE Egyetemi Könyvtárban = KKK (26.) 2017. 2. 17-22.

KnAPp Éva: Librum evolvo. Eszme- és könyvtörténeti tanulmányok a XVI-XX. századból. Bp.: Reciti, 2017. 319 p.

Koncz Pál: Papírmívesség és könyvművészet Veszprém megyében a 18-20. században / szerk. JAKAB Réka. Veszprém: Laczkó D. Múz., 2017. 383 p. ill.

KovÁCs Eszter: Myšlenky českých husitů a madarských jezuitů o osmanské expanzi = Kniha. (Martin, Slovenská Národná Kniznica) 2017. 18-26.

Magyar és cseh szerzők: Szántó Arator István, Pázmány Péter, Bartoloměj Dvorský és Václav Budovec török veszélyre figyelmeztető müveiröl és közös forrásaikról

KRÁsz Lilla: Képzés, hivatás, önreprezentáció. Az „ideális orvos” társadalmi-kulturális képlete a 18. századi Magyarországon =Turul (90.) 2017. 1. 28-33.

Könyvtártörténeti adatokkal

MoNOK István: A szakkönyvtárak szerepe a tudományos kutatás szabadságának kivívásában. Egy európai történet, magyarországi példákkal = KKK (26.) 2017. 11. 39-45. 
A 2017. október 12-13-án Pécsett tartott University and universality - the place and role of the University of Pécs in Europe from the Middle Ages to present day címú nemzetközi egyetemtörténeti konferencián elhangzott előadás szerkesztett változata

MonoK István: Kulturális digitalizálás. A könyvnyomtatás ígéret volt - és az internet? = KF (27.) 2017. 1. 36-41.

A „Digitális transzformáció” c. konferencián, 2016. febr. 11-én elhangzott előadás szerkesztett, bővített változata.

MonoK István: A tudás változásai, egy olvasmánytörténész szemével = MTud (178.) 2017. 11. 1369-1375.

MonoK István: Giambattista Bodoni könyveinek ismerete Magyarországon és Erdélyben a 18. század végén és a 19. század elején = A Telekiek és a kultúra... 129-138., 327., 334.

Monok István: Die Rolle der Fachbibliotheken im Kampf um die Meinungsfreiheit der wissenschaftlichen Forschungen. Eine europäische Geschichte mit ungarischen Beispielen = University and universality... 217-227.

A konferencián elhangzott előadás szerkesztett, magyar nyelvü változata megjelent a Könyv, könyvtár, könyvtáros 2017/11. számban

MonoK István: A katalógusok és könyvjegyzékek recepciótörténeti forrásértékéről = Az Eszterházy Károly Egyetem tudományos közleményei (44.) 2017. 231-237.

NAGY Kornél: Egy 17. századi örmény katolikus Breviárium az MTA Könyvtárának Keleti Gyüjteményében = MKsz (133.) 2017. 2. 197-212. ill.

ORBÁN János: Teleki Sámuel marosvásárhelyi könyvtáráról és gyüjteményeiröl = MKsz (133.) 2017. 4. 427-454. ill.

Perényi Péter-Hirschfogel, Augustin: Concordantz des Alten und Neuen Testaments = Egybecsengés az Ó- és Újtestamentumban Páty: Hármashullám, 2017. 159 p. ill.

Téglásy Imre tanulmányával.

Az eredeti dokumentum (Wienn: Adler, 1550) fotómásolatával és magyar nyelvü fordításával.

PoGÁNY György: A Dante Könyvkiadó ifjúsági könyvei = KN (19.) 2017. 4.71-91.

A reformáció könyvespolca. Reprezentatív kiadványok Magyarországon a reformáció korából / szerk. P. VÁsÁRHELYI Judit. Bp.: OSZK - Argumentum K., 2017. 148 p. ill. (A Magyar Könyvszemle és a MOKKA-R Egyesület füzetei; 9.)

A 2017. okt. 16-án Budapesten, az Országos Széchényi Könyvtár által azonos címmel rendezett konferencia előadásainak szerkesztett anyaga

SELÁf Levente: Szent Albanus magyar királyfi francia nyelvü legendája (Vie de Saint Albain, roi de Hongrie) $=$ MKsz (133.) 2017. 4. 460-465.

SHERwood, Peter: Adalék Sir John Bowring magyarországi kapcsolataihoz = MKsz (133.) 2017. 3. 358-359.

SzABÓ András: Coetus Ungaricus. A wittenbergi magyar diáktársaság, 1555-1613. Bp.: Balassi - MTA BTK ITI Reneszánsz Oszt., 2017. 381 p. ill. (Humanizmus és reformáció; 37.) Kiadás-könyv- és könyvtártörténeti adatokkal

SzÉLl Anita: Heltai Gáspár magyarországi és erdélyi részleges „szemléje” 1879-től 2011-ig = Hortus amicorum. Köszöntökötet Egyed Emese tiszteletére / szerk. BARTHA Katalin Ágnes. Kolozsvár: Erdélyi Múzeum-Egyes., 2017. 122-130.

SzEnCI MolnÁR Albert: Secularis concio euangelica, az az jubileus esztendei praedikatzo [!], mellyben az euangeliumnac ez elött száz esztendövel Isten kegyelméböl uyonnan kinyilatkoztatása [!], terjedése és megtartása örvendetes haláadással elöszámláltatic es megdiczirtetic. Németül praedikáltatott Haydelbergában ... az Sz. Lélec nevö öreg egyházban, Mindszent hónac 2. napján 
1617. esztendöben Scultetus Abraham által. Bp.: Balassi - OSZK, 2017. Hasonmás kiad. 109 p. ill. + mell. (35 p.) (Bibliotheca Hungarica antiqua; 45.)

A mellékletben Imre Mihály tanulmányával.

TÉGLÁsy Imre: „Deine Arbeit ist gottgefällig”. Nachwort zur Concordantz (Wien, 1550) = PerÉNYI

Péter-Hirschfogel, Augustin: Concordantz des Alten und Neuen Testaments. Páty: Hármashullám, 2017. 91-114.

A tanulmány magyar változata: 117-144.

TÉGLÁsY Imre: „Istennek tetsző a te munkád...”. Utószó az Egybecsengés (Bécs, 1550) modern kiadásához Concordantz des Alten und Neuen Testaments. Páty: Hármashullám, 2017. 117-144. A tanulmány német fordítása: 91-114.

A Telekiek és a kultúra. A 2016. októberi marosvásárhelyi konferencia tanulmányai/ szerk. BÁNYAI Réka. Marosvásárhely: Teleki Téka Alapítvány, 2017. 338 p. ill.

То́тн Árpád: Johann Gottfried Prixner rézmetsző német evangélikus polgári háttere = Térképtörténeti Közlemények... 95-113. ill.

Lipszky János Mappa generalisának keletkezéstörténetéhez

То́тн Zsombor: A kora újkori könyv antropológiája. Kéziratos irodalmi nyilvánosság Cserei Mihály (1667-1756) írás- és szöveghasználatában. Bp.: Reciti, 2017. 379 p. (Irodalomtörténeti füzetek, 178.)

Könyvtörténeti adalékok: Cserei Mihály olvasmánymüveltségéről

TÚRI Klaudia: Egy szeráfi prognosztikon = Lelkiség és irodalom... 475-479. ill.

Uy Testamentum mag(y)ar n(y)elwen(n) mell(y)et az Görög és Diak n(y)elvböl uyonnan fordijtank, az Mag(y)ar nipnek Kereszt(y)en hütben valo ippülisire / ford. Sylvester János. Bp.: Kossuth - MTA KIK, 2017. Hasonmás kiad. 783 p. ill.

Zvara Edina tanulmányával.

ÚJVÁRY Zsuzsanna, J.: A kassai protestáns polgárok műveltsége és kapcsolatrendszere a XVII. század első felében $=$ Reformáció és katolikus megújulás. Tanulmányok a reformáció kezdetének 500. évfordulójára. Vác: Mondat Kft., 2017. 70-91.

Mecenatúrára, könyvgyüjtésre vonatkozó adatokkal

Erősen rövidített változat: Kassa város polgárainak mủveltsége és mecenatúrája a 17. század első felében $=$ Testimonio litterarum. Tanulmányok Jakó Zsigmond tiszteletére / szerk. DÁNÉ Veronka, LuPEscuné MaKó Mária, Sipos Gábor. Kolozsvár: Erdélyi Múzeum-Egyes., 2016. 419-427.

„Üstököst látni”. Az 1680. évi üstökös művelődés- és tudománytörténeti emlékei / szerk. FARKAS Gábor Farkas, Szebelédi Zsolt, VArga Bernadett, Zsoldos Endre. Bp.: MTA KIK - Jaffa K., 2017. 597 p. ill. (Lichniae)

A kötet négy 17. századi forrás hasonmás közlését, betűhủ átiratát és magyar nyelvű fordítását tartalmazza

VARGA Bernadett: „Hát én Uram, mit szóljak te elötted?”. Keresztúri Bíró Pál és a Mennyei társalkodás. Bp.: OSZK, 2017. 212 p. ill.

Könyvtörténeti fejezettel: ,az elmélkedésnek mestersége egy a’ leg-szükségesebbek közzül”. A Mennyei társalkodás 18. századi sikertörténete: 93-104.

VÁSÁRHELYI Judit, P.: A régi magyarországi nyomtatványok bibliográfiai feldolgozása = MKsz (133.) 2017. 1. 102-105.

Hozzászólás Borda Lajos téziseihez. Országos Széchényi Könyvtár, 2016. március 2.

VERÓK Attila: Die hallisch-ungarischen Kulturkontakte im Spiegel der historischen Sammlungen der Franckeschen Stiftungen zu Halle (17-18. Jahrhundert) = Die Hungarica Sammlung der Franckeschen Stiftungen zu Halle. Alte Drucke 1495-1800 / Hrsg. Brigitte KLosterberg, Ist- 
ván Monok Bp.: MTA KIK, 2017. VII-XXXIX. (Adattár XVI-XVIII. századi szellemi mozgalmaink történetéhez; 40.)

VeróK Attila: Das Buch als Repräsentationsmittel bei den Siebenbürger Sachsen (15/16. Jahrhundert) = Zeitschrift für siebenbürgische Landeskunde (39.) 2016. 91-99.

VERÓK Attila: Ein anderer Blick auf die 500 jährige Bibliotheksgeschichte Siebenbürgens = Zeitschrift für siebenbürgische Landeskunde (39.) 2016. 122-132.

VISKOLCz Noémi: A nagyszombati református gyülekezet temploma és javai a 17. században = Publicationes Universitatis Miskolciensis. Sectio philosophica (21.) 2017. 2. 342-357. ill.

A nagyszombati református gyülekezet története, templomának javai és könyvtára

Voigt Vilmos: A Religio és Nevelés (1841-1849) és létrehozója: Szaniszló Ferenc = Lelkiség és irodalom ... 504-507.

Vörös Imre: Péczeli József, 1750-1792. Bp.: Universitas, 2017. 165 p. (Historia litteraria; 33.) A Mindenes Gyüjteményröl: 109-129.

A Bibliográfiában Péczeli József müvei korabeli kiadásainak, 1790-1992 között megjelent röpiratainak és ismeretterjesztő kiadványainak listájával

Zvara Edina: „Az magyar nípnek keresztyén hütben való ípülísire”. Sylvester János Újszövetségfordítása = Uy Testamentum mag(y)ar n(y)elwen(n) mell(y)et az Görög és Diak n(y)elvböl uyonnan fordijtank, az Mag(y)ar nipnek Kereszt(y)en hütben valo ippülisire / ford. SYLVESTER János. Bp.: Kossuth-MTA KIK, 2017. Hasonmás kiad. 767-780.

\section{Bibliográfiák, repertóriumok, katalógusok}

BoRVÖLGYI Györgyi: A magyar nyomda-, könyv-, sajtó- és könyvtártörténeti szakirodalom 2016ban = MKsz (133.) 2017. 4. 473-499.

Cartea românească veche în Imperiul Habsburgic (1691-1830). Recuperarea unei identităţi culturale = Old Romanian book in the Habsburg Empire (1691-1830). Recovery of a cultural identity / Ioan Chindriș et al. Cluj-Napoca: Mega, 2016. 1010 p. ill.

DEÁK Ágnes: Tiltott hazai könyvek és nyomtatványok jegyzéke -1863 tavasz = Acta Universitatis Szegediensis. Acta Historica 140. 2017. 3-22.

Die Hungarica Sammlung der Franckeschen Stiftungen zu Halle. Alte Drucke.1495-1800 / Hrsg. Brigitte Klosterberg, István MonOK. Bp. MTA KIK, 2017. 2 db. (1235 p.) (Adattár XVI-XVIII. századi szellemi mozgalmaink történetéhez; 40.) [1. köt.]: Bd. I. A-O; [2. köt.]: Bd. II. P-Z

KlimeKovÁ, Agáta - OndroušKovÁ, Janka: Bibliografia územne slovacikálnych tlačí 19. storočia. Martin: Slovenská Národná Knižnica, 2016- (Slovenská národná retrospektívna bibliografia. Séria A. Knihy). [1. köt.]: Zv. 1. A-D. 2016. 424 p.; [2. köt.]: Zv. 2. E-J. 2016. 459 p.; [3. köt.]: Zv. 3., K-M. 2016. 455 p.; [4. köt.]: Zv. 4. N-R. 2017.389 p.

A mai Szlovákia területén (így a Felvidéken is) megjelent 19. századi nyomtatványok bibliográfiája

KNAPP Éva: A budapesti Egyetemi Könyvtár 1635 előtti ősállományának negyven új kötete = Librum evolvo... 2017. 225-254.

LAKATOS Éva: Kikötőben maradt hajók. Laptervezetek, meg nem jelent lapok válogatott bibliográfiája. Bp.: OSZK - Gondolat, 2017. 198 p. (Nemzeti téka)

Mizera Tamás - NAGY Andor - Verók Attila: A könyvkiadó egri Líceum. Történet és kiadványjegyzék. Bp.: Kossuth; Eger: EKE, 2017. (Kulturális örökség). [1. köt.] 1755-1852. 493 p.: ill.; [2.köt.] 1853-1949. 458 p.

PÁszTI László: Hungarika-térképek a Humboldt Egyetem Földrajzi Intézetének Térképgyüjteményében. Térképkatalógus $=$ Térképtörténeti Közlemények... 59-94. ill. 
Petrik Géza: Magyarország bibliographiája, 1712-1860 = Bibliographia Hungariae 1712-1860 / összeáll. ... Petrik Géza; Bp.: OSZK, 1968-

9., Pótlások Petrik Géza Magyarország bibliographiája 1712-1860 c. múvéhez. 1701-1800 között megjelent magyarországi (és külföldi magyar nyelvü) nyomtatványok = Additamenta ad opus Géza Petrik Bibliographia Hungariae 1712-1860. Catalogus librorum annis 1701-1800 in Hungaria (alibique lingua Hungarica) editorum /összeáll. és szerk. KovÁcs Eszter, V. ECSEDY Judit. 2017. 495 p.

RÁcz Emese: A nagyenyedi Bethlen-kollégium könyvtárának katalógusai a 18. század derekán = Hortus amicorum. Köszöntőkötet Egyed Emese tiszteletére / szerk. BARTHA Katalin Ágnes. Kolozsvár: Erdélyi Múzeum-Egyes., 2017. 131-135.

SALGÓ Ágnes, W.: A Pannonhalmi Főapátsági Könyvtár ősnyomtatványai. PFK-INC = Incunabula Bibliothecae Sancti Martini de Sacro Monte Pannoniae. Pannonhalma: Pannonhalmi FőapátságBencés K., 2017. 258 p. (Catalogi Bibliothecae Sancti Martini de Sacro Monte Pannoniae; 2.)

A Szegedi Tudományegyetem Klebelsberg Könyvtár ősnyomtatványai. Kiállítás a Klebelsberg Könyvtárban. 2017. április 24 - május 15. = Die Inkunabeln der Klebelsberg-Bibliothek Szeged. Ausstellung in der Klebelsberg-Bibliothek. 24. April-15. Mai 2017. / összeáll. VARGA András, FARKAS Katalin. Szeged: SZTE Klebelsberg Kvt., 2017. 55 p. ill.

\section{Cenzúratörténet és más jogi szabályozások}

Az első világháború sajtójogi forrásai. Sajtójog a kivételes hatalom árnyékában / szerk. KeLEMEN Roland. Bp.: Médiatud. Int., 2017. 311 p. (Médiatudományi könyvtár, 28.)

ForGó András: Bibliaégetés Egerben? Néhány gondolat Komáromi Csipkés György Bibliájának sorsáról = Lelkiség és irodalom... 152-159.

KELEMEN Roland: Sajtójog és sajtószabadság: az első világháborús kivételes hatalmi szabályozás = Az első világháború sajtójogi forrásai: sajtójog a kivételes hatalom árnyékában / szerk. KeLEMEN Roland. Bp.: Médiatud. Int., 2017. 35-62.

KELEMEN Roland: Sajtókorlátozás az első világháborúban: egy alapjog léte az első világháborús kivételes hatalmi szabályozás árnyékában = Iustum aequum salutare (13.) 2017. 4. 113-126.

NAGY Gábor, Sz: A koalíciós korszak sajtójogi szabályozása 1945-1949 között = Múltunk (62.) 2017. 4. 190-213.

NAGY Gábor, Sz.: „Tüzpróbája lehet a magyar demokráciának”. A sajtótermékek és terjesztésük engedélyezésének ideiglenes rendezése 1947 őszén = Kommentár (Budapest) (12.) 2017. 4. 11-21. ill.

PAÁL Vince: Az 1914. évi sajtótörvény-javaslat képviselőházi vitája = In medias res (6.) 2017. 1. $1-47$.

RÉvÉsz T. Mihály: A sajtószabadság „örömünnepe” 1867 Magyarországán = In medias res (6.) 2017. 1. 92-104.

RÉvÉSz T. Mihály: A „füstbement” tervezet, s ami utána következett... (Az első magyar sajtótörvény kálváriája) = Studia in honorem István Stipta / szerk. BALOGH Judit et al. Bp.: KRE ÁJK, 2017. 351-375.

RÉvÉsz T. Mihály: A sajtószabadság ügye 1847 Magyarországán = Unitas multiplex. Ünnepi tanulmányok Szigeti Péter 65. születésnapjára / szerk. TAKÁCs Péter. Bp.: Gondolat; Győr: SZE DFK, 2017. 291-305.

RÉVÉsz T. Mihály: Az első sajtótörvény reneszánsza a kiegyezés Magyarországán = Ünnepi tanulmányok Máthé Gábor oktatói pályafutásának 50. jubileumára. Studia sollemnia scientiarum politico-cameralium / szerk. Kis Norbert, Peres Zsuzsanna. Bp.: Dialóg Campus, 2017. 325-335. 


\section{Könyvtörténet / Kéziratosság, kódexek}

BÁNDI András - SzABÓ András Péter: Hajdú István törcsvári porkoláb kéziratos kötete. Két ismeretlen magyar vers Báthori Gábor fejedelem korából = MKsz (133.) 2017. 2. 129-155.

A kötetben olvasható néhány forrás szövegközlésével

Bolonyal Gábor: Poet in the sky - Naldo Naldi's Portrait of Pindar in his Encomium of the Corvinian Library $=$ A home of arts and muses... 63-75. ill.

BoreCZKy Anna: Epizódok Apollonius király históriájának középkori hagyományozódástörténetéből. Szövegváltozatok és képi elbeszélések = Fordítás, tolmácsolás, értelmezés... 213-225. ill. A bemutatott példányok között van az Országos Széchényi Könyvtárban örzött Apollonius pictus (Cod. Lat. 4.) kódexe is

BuJTÁs László Zsigmond: Apáczai Csere János könyvajándéka = Egyháztört. Szle (18.) 2017. 3. 147-153. ill.

Csorba Dávid: Hungaricák Canterbury érsekének könyvtárában = Egyháztört. Szle (18.) 2017. 1. 114-117.

DeÉ NAGY Anikó: Teleki Sámuel úti jegyzeteinek hányattatásai = A Telekiek és a kultúra... 113127. 327. 334 .

A tanulmány szerzője Teleki Sámuel útinaplóját, mint könyvtáralapításával kapcsolatos forrást is tárgyalja

Dомокоs György: A ELTE Egyetemi Könyvtár Vergerio-grammatikája (Cod. Lat. 23) = Hagyományok és kihívások V. Múlt és jövő. Országos Könyvtárszakmai Nap, 2016. / szerk. SzABó Panna, SzÉKelyné TöröK Tünde. Bp.: ELTE Egyetemi Kvtára és Lvtára, 121-134.

FARKAS Gábor Farkas: The Odyssey of the Székely Chronicle and a Manuscript of Poems = Kniha. (Martin, Slovenská Národná Kniznica) 2017. 27-34.

FARKAS Gábor Farkas - BoÉr Hunor: Ferencesek és székelyek. Két elrejtett kincs a páncélszekrény mélyéről = MKsz (133.) 2017. 1. 89-95.

FARKAs Gábor Farkas - HorvÁth Mária, M. - KöRmendy Kinga - Szebelédi Zsolt: Andrássy Ignác Biblia pauperuma $=$ MüvtörtÉrt (66.) 2017. 2. 321-328.

FEKETE Csaba: Komáromi Jánosok = MKsz (133.) 2017. 1. 81-88.

Az OSZKK Oct. Hung. 136 jelzetű kézirat feltételezett másolójáról

FöLDEsI Ferenc: Árkosi Benedek imádságoskönyvének két kéziratcsoportja = A reformáció könyvespolca... 126-136.

HoffmANN Gizella: Rövid históriája az cseh országi ecclésiák üldöztetésének... Észrevételek Comenius Historia persecutionum Ecclesiae Bohemicae címü múvének ismert és ismeretlen magyar fordításaihoz (1710 k.-1795). Mủhelytanulmány-vázlat = Fordítás, tolmácsolás, értelmezés... 50-64. ill.

A home of arts and muses. The library of King Matthias Corvinus / ed. by Edina ZsupÁn. Bp.: Bibl. Nationalis Hungariae, 2017. 212 p. ill. (De Bibliotheca Corviniana). (Supplementum Corvinianum; 4.)

A Milánóban, 2015. okt. 9-én rendezett konferencia szerkesztett anyaga.

Hubert Gabriella, H.: Graduál-énekeskönyv mint reformációs könyvmüfaj = A reformáció könyvespolca... 64-71. ill.

Katona Tünde - LATZKovits Miklós: A harántoktáv alakú albumok poétikája 2. = Hortus amicorum. Köszöntő kötet Egyed Emese tiszteletére / szerk. BARTHA Katalin Ágnes. Kolozsvár: Erdélyi Múzeum-Egyes., 2017. 136-148.

A címben jelzett (2.) a szerzők utalása arra, hogy jelen tanulmány egy korábbi, német nyelvü tudományos dolgozat jelentősen átdolgozott, bővített változata. Adatai: KATONA Tünde - LATZKOVITs Miklós: Die Poetik der Stammbücher in Queroktav (Überlegungen anhand der Weimarer 
Stammbuchsammlung) = ,swer sinen Vriunt behaltet, daz ist lobelich”. Festschrift für András Vízkelety zum 70. Geburtstag. / Hrsg. Márta NAGY, László JóNÁcsIK. Piliscsaba-Bp., 2001. 289-301.

Kocsis Réka, P.: Marginálistípusok az ómagyar nyelvemlékkódexekben = Magyar Nyelv (113.) 2017. 1. 42-49.

KONRÁD Eszter: Sienai Szent Katalin magyarországi kódexekben $=$ Az első 300 év Magyarországon és Európában. A Domonkos-rend a középkorban / szerk. Csurgai HoRvÁtH József. Székesfehérvár: Alba Civitas Tört. Alapítvány, 2017. 165-180. ill.

Korompay Klára: Egy nyitott kérdés, több tudományterület metszéspontjában: az ún. Huszita biblia = Husz János és a huszitizmus... 53-63.

Korondi Ágnes: A Kazinczy-kódex Szent Jeromos hatalmát illusztráló exemplumának forrásáról = Lelkiség és irodalom... 289-293.

KÜHRNER Éva: Egy ősnyomtatványról a SZAGKHF könyvtárának kötete kapcsán = Athanasiana 44. 2017. 202-210.

KÜHRNER Éva: A „nyomdászok királyának” kötetei könyvtárunk gyüjteményében = Athanasiana 45. 2017. 169-178. ill.

LATZKovits Miklós - RAB Irén: Az Inscriptiones Alborum Amicorum és Podmaniczky Sándor (17581830) emlékkönyvei = A báró Podmaniczky család szerepe a 18-19. századi magyar kultúrában / szerk. GuRKa Dezső. Bp.: Gondolat, 2017. 55-72. ill.

LAUF Judit: Az Esztergomban örzött huszita antifonále kodikológiai vizsgálatának néhány eredménye és az Urunk színeváltozása zsolozsmaszövegének közlése = Husz János és a huszitizmus... 73-89.

Az Esztergomi Főszékesegyházi Könyvtár Ms. 313. jelzetü kódexéről

LAUF Judit: Újfalusi Judit glosszái az Érsekújvári kódexben? = Lelkiség és irodalom... 299-304. ill.

MADAs Edit: Az Érsekújvári kódex Szent Flórián-legendájának forrása = Lelkiség és irodalom... $310-315$.

Az eredeti latin nyelvű szöveg és az Érsekújvári kódexben olvasható magyar fordítás szövegközlésével

MADAs Edit: À la recherche des sources liturgiques et hagiographiques du culte des saints rois hongrois en Europe centrale = Les saints et leur culte en Europe centrale au Moyen Âge XIe-début du XVIe siécle / Études réunies par Marie-Madeleine dE CEvins, Olivier MArIn. Turnhout: Brepols, 2017. 281-291.

A tanulmány a következő tudományos dolgozat bővített változata: A magyar szent királyok közép-európai kultusza liturgikus és hagiográfiai források tükrében = Ars Hungarica (39.) 2013. 2. Liber decorum. Wehli Tünde köszöntése 2. 145-152.

Mezer Zsolt: Újabb adatok Kalmár György könyveiről = Acta Papensia (17.) 2017. 1/2. 143-152. MoNOK István: Farsangi versek, vagy tréfás mulatságok, 1790. Balogh István kézirata az Országos Széchényi Könyvtárban = Lelkiség és irodalom... 333-336.

Az Országos Széchényi Könyvtár Quart. Hung. 146. jelzetű kéziratáról

NÉmeth András: Il copista Giovanni Scutariota e la fortuna dei manoscritti greci di Giano Pannonio e Mattia Corvino = A home of arts and muses... 89-111. ill.

OLÁH Róbert: Melius Juhász Péter saját kezủ ajánlásai = Collegium Doctorum. (13.) 2017. 1. 7690. ill.

Papahagi, Adrian: A Fragment of the Graduale Varadiense at the Romanian Academy Library in Cluj (Kolozsvár) = MKsz (133.) 2017. 4. 455-459. ill. 
Pócs Dániel: Egy corvina története. Battista Spagnoli Mantovano: Parthenice Mariana. Pontosításokkal a Pierpont Morgan Library M496 és M497 jelzetű corvináinak provenienciájához = Ars Hungarica. (43.) 2017. 3. 301-353. ill.

Az Országos Széchényi Könyvtár Cod. Lat. 445. jelzetű kódexéről

Pócs Dániel: The history of a Corvina codex. Battista Spagnoli Mantovano: Parthenice Mariana. With some notes on the provenance of Ms. M496 and M497 of The Pierpont Morgan Library, New York = A home of arts and muses... 141-202. ill.

SCHELHAMmer Zsófia: Nők az albumok lapjain = Az ember - kultúrtörténeti és poétikai megközelítésben. Fiatalok Konferenciája 2016 / szerk. DérI Eszter et al. Bp.: Reciti, 2017. 221-235. ill.

A tanulmány az albumbejegyzések elemzésével a magyarországi nők olvasmánytörténetéhez szervesen kapcsolódik

SzÁRAz Orsolya: Gyalogi János kéziratos prédikációja 1728-ból = Lelkiség és irodalom... 386-395.

A Batthyaneum (Gyulafehérvár) Ms. XI. jelzetű kéziratában található prédikációról a szöveg közlésével

Uhrin Dorottya: Antiochiai Szent Margit legkorábbi magyarországi kultusza. Álmos herceg egyházalapításai és a Szent Margit-szakramentárium = MKsz (133.) 2017. 1. 13-31.

\section{Nyomda-, nyomdászattörténet}

\section{Több évszázadot érintö munkák}

ECSEDY Judit, V.: Vermutliche und tatsächliche druckorte im Banat = Deutsche Sprache und Kultur im Banat. Studien zur Geschichte, Presse, Literatur und Theater, sprachlichen Verhältnissen, Wissenschafts-, Kultur- und Buchgeschichte, Kulturkontakten und Identitäten / Hrsg. Wynfried Kriegleder, Andrea Seidler, Jozef Tancer. Bremen: Lumiére, 2015. 39-49. ill.

NAGY Andor: A könyvkiadó egri Líceum tevékenysége a statisztikai adatok tükrében (1755-1949) = Mizera Tamás - NAGY Andor - VeróK Attila: A könyvkiadó egri Líceum. Történet és kiadványjegyzék. Bp.: Kossuth; Eger: EKE, 2017. (Kulturális örökség). 37-54.

VERók Attila: A Typographia Lycei Episcopalistól az Érseki Líceumi Nyomdáig. Az egri egyházi nyomdászat kétszáz éve (1755-1949) = MizerA Tamás - NAGY Andor - VeróK Attila: A könyvkiadó egri Líceum. Történet és kiadványjegyzék. Bp.: Kossuth; Eger: EKE, 2017. (Kulturális örökség). 9-36.

16. század

BÁNFI Szilvia: Gyulafehérvári nyomdászat. Négyszázötven évvel ezelőtt indult meg a nyomtatás a fejedelmi székhelyen, Gyulafehérváron $=$ MG (61.) 2017. 6. 69-71. ill.

MésZÁros Andor: A cseh exulánsok és nyomdáik Magyarországon = Husz János és a huszitizmus... 91-95.

SzABÓ András: Mantskovit Bálint Vizsolyban = Index biblicvs, az az: az egez Szent Iras könyveinec kentsere vezerlö, mutato es indito laistroma, melly által kitsiny munkáual az egész Bibliában bé foglaltatott szent irásokat caputon és versenként az kiuáltképpen valo tudtodra szükséges tzickelekuel egybe, nagy hamarsáual meg találhadd, az abece betüinec rendi szerint / ... magyarrá ford. ... MAntsKoutt Bálint által. Miskolc: Tiszáninneni Református Egyházker.; Sárospatak: Hernád, 2016. Hasonmás kiad. 25-38. 
17. század

ECSEDY Judit, V.: Bécsi nyomdák - magyar könyvek = MG (61.) 2017. 5. 68-71. ill.

17-18. század

ECSEDY Judit, V.: Zsolna. Egy különleges nyomdahely = „Üstököst látni”... 487-510. ill.

ILYÉs BARTHA Hajnalka: Almanacs Printed in Cluj in the 17th Century = Philobiblon (21.) 2016. 1. 43-57.

18. század

ECSEDy Judit, V.: Das deutschsprachige Bücherangebot kroatischer Druckereien im 18. Jahrhundert $=$ Deutsche Sprache und Kultur in Kroatien. Studien zur Geschichte, Presse, Literatur und Theater, sprachlichen Verhältnissen, Wissenschafts-, Kultur- und Buchgeschichte, Kulturkontakten und Identitäten / Hrsg. Wynfrid Kriegleder, Andrea Seidler, Jozef Tancer. Bremen: Lumière, 2017. 93-102.: ill.

ECSEDY Judit, V.: A marosvásárhelyi könyvnyomtatás kezdetei = A Telekiek és a kultúra... 183-211. 329. 336. ill.

A Függelékben a nyomdából 1786-1794 között kikerült kiadványok jegyzékével.

Hendre Bíró, Doina: Le contexte politique et les conditions d'achat de l'ancienne imprimerie des jesuites par Ignace Batthyány, évêque de Transylvanie = Ex oriente amicitia... 309-326.

18-19. század

HoRvÁth József: Fejezetek a győri nyomdászat történetéből 1. A Streibig-nyomda (1727-1850)= MG (61.) 2017. 2. 64-71. ill.

Mizera Tamás: „Athéné szerény gyermekei”. Tanítók emlékezete az egri Érseki Líceumi Nyomda kiadványainak tükrében, a kézisajtó (1755-1852) időszakában = A könyvkiadó egri Líceum: történet és kiadványjegyzék / MizerA Tamás - NAGY Andor - VeróK Attila: A könyvkiadó egri Líceum. Történet és kiadványjegyzék. Bp.: Kossuth; Eger: EKE, 2017. (Kulturális örökség). $55-66$.

VERÓK Attila: Eszterházy Károly és egri nyomdája = Karol Eszterházy a jeho tlačiareň v Jágri = Az Esterházyak fraknói ifjabb ága / összeáll. ... STREŠŇÁK Gábor. Szenc: s. n., 2017. 402-429. ill. A tanulmány bilingvis formában (magyar és szlovák nyelven) jelent meg

19. század

HoRVÁTH József: Fejezetek a győri nyomdászat történetéből 2. A 19. század második felének nyomdáiról = MG (61.) 2017. 4. 44-50. ill.

ILYÉs BARTHA Hajnalka: Szemelvények a Kolozsvári Lyceum Nyomda történetéből (1861-1864)= Certamen IV. Előadások a Magyar Tudomány Napján az Erdélyi Múzeum-Egyesület I. Szakosztályában. Nyelv-, irodalom-, néprajztudomány, múvészettörténet, történelem. / szerk. EGYED Emese, GÁlfi Emőke, WeIsz Attila. Kolozsvár: Erdélyi Múzeum-Egyes., 2017. 71-79. 
KarlinszKy Balázs: A veszprémi Egyházmegyei Könyvnyomda = Veszprémi Szle (19.) 2017. 2. $61-74$.

KIs Krisztián Bálint: Rövid szolnoki nyomdászattörténet = MG (61.) 2017. 3. 66-69. ill. „A nyomtatott szó hatalma. Nyomdák és nyomtatványok Szolnokon” címü, 2015. október 30án a Verseghy Ferenc Könyvtárban elhangzott előadás szerkesztett változata. A dolgozat az eddig nem kutatott helyi nyomdászatról ad áttekintést.

KIs Krisztián Bálint: Kárpátalja nyomdászata a kezdetektől 1918-ig= MG (61.) 2017. 4. 52-55. ill.

20. század

HoRVÁTH József: Fejezetek a győri nyomdászat történetéből 3. A 20. század első felének nyomdáiról $=\mathrm{MG}$ (61.) 2017. 6. 62-68. ill.

\section{Könyvmüvészet, illusztráció, ex libris}

BÁNFI Szilvia: A fiumei Szent Vid-templom Csodakeresztjét ábrázoló újabb rézmetszetváltozat = Lelkiség és irodalom... 46-50. ill.

BoreczKy Anna: A budapesti Concordantiae Caritatis. Egy ciszterci apát középkori univerzuma egy bécsi városi tanácsos képeskönyvében. Szekszárd: Schöck Artprint Kft, 2017. 128 p.

Az 1413-ban Bécsben készült „Concordantiae caritatis” hasonmás kiadásának kísérökötete.

Boreczky Anna: The Budapest Concordantiae Caritatis. The Medieval Universe of a Cistercian Abbot in the Picture Book of a Viennese Councilman. Szekszárd: Schöck Artprint Kft, 2017. $128 \mathrm{p}$.

Az 1413-ban Bécsben készült „Concordantiae caritatis” hasonmás kiadásának kísérőkötete angol nyelven

Boreczky Anna: The Illustrated Life of Apolllonius and Tarsia. A „Papyrus-style”. Narrative in Ottonian Art = Classical Heritage and Medieval Innovation: Illustrated Texts from Late Antiquity to the Early Middle Ages. Convivium III/1./ ed. Anna BoreczKy. Brno: Masarykova Univerzita, 2016. 76-91. ill.

Az Országos Széchényi Könyvtár Cod. Lat. 4. jelzetű, illusztrált késő antik regényéről (Apollonius király históriája)

DEÁK Éva: Magyar és oszmán-török férfiviseletek 17-18. századi viseletképeken = Török hagyaték. Tanulmányok a magyar kultúra török kapcsolatairól / szerk. BARTHA Júlia, HoPPÁL Mihály. Bp.: Európai Folklór Központért Egyes., 2017. 249-276. ill.

GöDöLLE Mátyás: V. Ferdinánd 1830. évi pozsonyi koronázásának ábrázolásai = Egy elfeledett koronázás a reformkorban: az utolsó pozsonyi uralkodókoronázás 1830 őszén / szerk. Soós István. Bp.: MTA BTK Törttud. Int., 2017. 105-130. 275-329. ill.

GyULAI Éva: Mikoviny Sámuel rézmetszete a diósgyőri várról Aszalay Ferenc rajza alapján $(1730$ k.) = Lelkiség és irodalom... 165-171. ill.

KNAPP Éva: Zrínyi Miklós Adriai tengernek Syrenaia (Bécs, 1651) - a díszcímlap könyvészeti, ikonográfiai és irodalmi értelmezéséhez $=$ KF (27.) 2017. 2. 226-231. ill.; = Librum evolvo... 35-41.

KNAPP Éva: Arbor haereseon = Librum evolvo... 21-33. 
KRISTÓF Ildikó, Sz.: Anthropologie dans le calendrier. La représentation des curiosités de la nature et des peuples exotiques dans les calendriers de Nagyszombat (Tyrnavia), 1676-1773 = Ex oriente amicitia... 87-113. ill.

Nagyszombatban megjelent kalendáriumok antropológiai témájú illusztrációi

Mıкó Árpád: Festett oklevelek és kódexek a késő középkori Magyarországon. A művészettörténész dilemmái = MüvtörtÉrt (66.) 2017. 2. 303-311. ill.

NÉmETH András: Continuous Narration through Scenic Depictions. The Apollonius pictus = Classical Heritage and Medieval Innovation: Illustrated Texts from Late Antiquity to the Early Middle Ages. Convivium III/1./ ed. Anna Boreczky. Brno: Masarykova Univerzita, 2016. 106-121. ill. Az Országos Széchényi Könyvtár Cod. Lat. 4. jelzetü, illusztrált antik regényéröl (Apollonius pictus)

SzALAI Béla: Szakáll János ismeretlen Kolozsvár látkép-metszete 1752-ből = MKsz (133.) 2017. 3. 352-357. ill.

То́тн Ferenc: Szent Márton magyar lovasként való ábrázolása a tours-i Szent Márton bazilika káptalanjának 1635-ös breviáriumában $=\mathrm{MKsz}$ (133.) 2017. 3. 346-351. ill

Zsupán Edina: A Corvina könyvtár „első címerfestője”. Stílushüség és imitáció. A Philostratus- és a Ransanus-Corvina provenienciájához= MủvtörtÉrt (66.) 2017. 2. 273-302. ill.

Az Országos Széchényi Könyvtárban őrzött Cod. Lat. 417. és Cod. Lat. 249. jelzetü Corvina kódexről

\section{Kisnyomtatványok}

FÖRKÖLI Gábor: „Virtus Seriniana”. Egy iskolai Zrínyi-óda útja Gdańsktól Párizsig (1664)= MKsz (133.) 2017. 2. 156-173.

A vers latin és német nyelvű változatának szövegközlésével

KNAPP Éva: „Az árvák fohásza”. Többfunkciós marcali ponyvanyomtatványok = Doromb 2017. 5. 345-358. 398.; = Librum evolvo... 119-132.

A függelékben a marcali v. Kovácsffy Arnold (1898-1944) nyomdájában 1930-1931-ben készült 7, illetve a Mizsur Ádám gyorssajtója alól, a század első két évtizedéből származó 1 nyomtatvány szövege

KNAPP Éva: Ismeretlen 18. századi magyarországi nyomtatványok. 3. = MKsz (133.) 2017. 2. 237 245. ill.

A tanulmányban említett, Magyarországon ritka iskoladráma szövegének közlésével

Kотнеncz Kelemen: A Hajós környéki táj 19. századi vallásos ponyvanyomtatványai = Vallásos kultúra és életmód a Kárpát-medencében 10. Konferencia Veszprémben a Laczkó Dezső Múzeum és a Veszprémi Hittudományi Főiskola közös szervezésében. 2014. május 20-23. / szerk. PilipKó Erzsébet, Fogl Krisztián Sándor. Veszprém: Laczkó D. Múz., 2017. 968-983.

NAGY Andor: Wittenbergi nyomtatványok Joseph Trausch kéziratgyüjteményéből = Az Eszterházy Károly Egyetem tudományos közleményei 44. 2017. 239-250.

A brassói fekete templom levéltárában található dokumentumokról. A wittenbergi nyomtatványok listájának közlésével

NAGY Andor: Gelegenheitsdrucke in der Handschriftensammlung „Joseph Franz Trausch” in Kronstadt $=$ Zeitschrift für siebenbürgische Landeskunde (39.) 2016. 163-174. 


\section{Térképészet}

DANKU György: A Széchényi Könyvtár Térképtárának új szerzeménye, A New Mapp of the Kingdom of Hungary and the Adjacent Countries by Phil. Lea = Térképtörténeti Közlemények... 9-25. ill.

Az OSZK Térképtár TR 3100 jelzetü példányáról és kiadásváltozatairól

DANKU György: Luigi Ferdinando Marsigli. Fordulat Magyarország térképi ábrázolás történetében = Térképtörténeti Közlemények... 47-58. ill.

KAPITÁNY Adrienn: Birodalmi úttérkép és nemzeti függetlenség. Egy országos sérelem 1835-ből = Aetas (32.) 2017. 2. Jókai Mór és a történelem. 55-75. ill.

PÁszTI László: Lipszky János Tabula generalis Regni Hungariae című térképének utóélete = Térképtörténeti Közlemények... 39-46. ill.

PÁszTI László: Edmund von Zuccheri Magyarország-térképei = Térképtörténeti Közlemények... 115-127. ill.

A térképek jegyzékével

PÁszTI László: Kiegészítés a Lipszky-térképek és feldolgozásaik jegyzékéhez = Térképtörténeti Közlemények... 129-144. ill.

Térképtörténeti Közlemények 1. Az Országos Széchényi Könyvtár Térképtárának évkönyve 2016. / főszerk. PÁszTi László. Bp.: OSZK, 2017. 158 p. ill.

\section{Papír}

Mór György: Az Oktoih I-IV könyv vízjelei, 1494 = MVízjel (15.) 2017. 40. 27-38.: ill.

Mór György-Stevanović, Zoran: Vízjelek a Vajdasági Levéltár protestánsokról szóló irataiban = MVízjel (15.) 2017. 41. 17-28. ill.

PelBÁRT Jenő: Ratschach papírmalom IHS-vízjele, 1827 = MVízjel (15.) 2017. 38. 5-6. ill.

Pelbárt Jenő: Hrabóc papírmalom koronás magyar címer-vízjele, 1809 = MVízjel (15.) 2017. 38. 7-9. ill.

PelbÁRt Jenő: A Biblioteca Universitaria-Bologna levélpapírjának vízjele 1929-ből = MVízjel (15.) 2017. 38. 11-12. ill.

PelbÁrt Jenő: Fiumei RJE monogram = MVízjel (15.) 2017. 38. 22. ill.

Pelbárt Jenő: Szénási Lászlóné különgyűjtemény az MVA-ban. Szénási-vízjelek 2. rész= MVízjel (15.) 2017. 38. 23-31. ill.

PelbÁrt Jenő: Salve Palatia vízjel, 1949 = MVízjel (15.) 2017. 38. 32. ill.

PelbÁrt Jenő: Zólyomlipcse 2. papírmalom vízjelhasználata, 1779-1873 = MVízjel (15.) 2017. 38. 33-43. ill.

Pelbárt Jenő: Nagyméretű RJE monogram-vízjel, 1917 = MVízjel (15.) 2017. 38. 44. ill.

Pelbárt Jenő: Monogram-vízjelek. 2. rész = MVízjel (15.) 2017. 38. 45-50. ill.

Pelbárt Jenő: Magyar turul vízjelek = MVízjel (15.) 2017. 39. 9-17. ill.

Pelbárt Jenő: Szecessziós La Rose, RJE présel-vízjel 1901-ből = MVízjel (15.) 2017. 39. 18. ill.

Pelbárt Jenő: Szénási Lászlóné különgyűjjtemény az MVA-ban. Szénási-vízjelek 3. rész MVízjel (15.) 2017. 39. 45-50. ill.

PelbÁRT Jenő: Két hermaneci óriás RJE monogram 1915-ből = MVízjel (15.) 2017. 40. 5-6. ill.

Pelbárt Jenő - Mór György: A futaki Hadik birtok iratainak vízjeleiről (1793-1847) = MVízjel (15.) 2017. 40. 17-24. ill.

Pelbárt Jenő - Mór György: A szentiváni parókia iratainak vízjeleiről (1801-1819) = MVízjel (15.) 2017. 40. 39-47. ill. 
PelbáRT Jenő: József Attila Medvetánc és Nagyon Fáj című verseskötetének diósgyőri vízjeleiről = MVízjel (15.) 2017. 41. 9-12. ill.

Pelbárt Jenő: Kodály Zoltán leveleinek vízjelei, 1907 = MVízjel (15.) 2017. 41. 13-15. ill.

Pelbárt Jenő: Új adat Pápa papírmalom alapításáról, 1715 = MVízjel (15.) 2017. 41. 16. ill.

PelbáRt Jenő: A budapesti Oktoih ősnyomtatvány vízjeleiről (1494) = MVízjel (15.) 2017. 41. 29-40. ill.

Pelbárt Jenő: Név-vízjelek 1. rész = MVízjel (15.) 2017. 41. 41-50. ill.

PelbáRT Jenő: A Diósgyőri Papírgyár vízjel-védjegyének története (1899-1949) = Papíripar. (61.) 2017. 1/2. 33-41. ill.

PelbáRt Jenő: A reformáció jelképei a magyar fehér mủvészetben. Bp.: M. Papírmúz., 2017. 234 p. ill.

A reformációhoz kötődő szimbólum-vízjelek katalógusa: 59-102.

\section{Könyvkötés-történet}

Mı́ó Árpád: Le legature in cuoio dorato e la Bibliotheca Corviniana a Buda = A home of arts and muses... 113-134. ill.

RozsondAi Marianne: Az ecclesia reformanda könyvkötéseken = Lyukasóra (26.) 2017. 8. 38-40. ill. То́тн Zsuzsanna: A Magyarországon élő evangélikus szlovákok rézveretes kötései és kialakulásuk $=$ Isis (17.) 2017. 64-77. ill.

\section{Könyvkereskedelem-terjesztés}

GranaszTór Olga: Éloge du roi de Prusse. Les connotations politiques d'un succès de librairie. La Prusse et la Hongrie entre 1780 et $1790=$ Ex oriente amicitia... 267-288.

GRANASZTór Olga: „Magyartalan könyvárosok”. Az első magyarországi könyvkereskedők megítéléséről a XVIII-XIX. század fordulóján= Programok és tanulmányok / szerk. BARTHA-KovÁCS Katalin, Penke Olga, SzÁsz Géza. Szeged: JATEPress, 2017. 141-150.

KovÁCs Ábrahám: Nemzetközi kálvinizmus Európa perifériáin. Magyar és skót protestáns kapcsolatok a 19. században. Bp.: L’Harmattan; Nagyvárad: PKE SITTI, 2016. 203 p. (Magyar protestáns teológiatörténeti könyvtár. Monográfiák)

A protestáns iratterjesztés és népi vallásos irodalom skót és angol közvetítői Magyarországon c. fejezet: $11-36$.

\section{Kiadástörténet}

\section{Több évszázadot érintö munkák}

TAKÁCS László: Az Officium Rákóczianum Szent Imre-himnuszai, avagy megjegyzések a szerzőség kérdéséhez = MKsz (133.) 2017. 1. 55-66.

16. század

BAJÁKi Rita: John Fischer imakönyve és annak fordítása = Lelkiség és irodalom... 35-41. ill. A RMNy 308A jelzetü kiadványáról és annak forrásáról. 
FeKete Csaba: Batizi és kátéja $=$ MKsz (133.) 2017. 3. 261-282.

OLÁH Róbert: Az 1567. évi debreceni zsinat nyomtatványai = A reformáció könyvespolca... 53-63. ill.

\section{6-17. század}

Horváth Csaba Péter: Jegyzet Telegdi Miklós katekizmusáról = Lelkiség és irodalom... 199-202. MonoK István: Peter Felckmann, egy elfeledett szász grécista = ItK (121.) 2017. 3. 392-397.

Peter Felckmann az Athanasius-kódex 1601-es kiadásában betöltött szerepéröl

Perger Péter: Régi magyarországi csillagászati nyomtatványok = „Üstököst látni”... 390-405.

VÁSÁRhelYI Judit, P.: Szenci Molnár Albert: Psalterium Ungaricum. Kis katekizmus. Herborn, 1607 $=$ Psalterium Ungaricum, Szent David kiralynac es prophetanac szaz ötven soltari az franciai notáknac és verseknec módgyokra most úyonuan magyar versekre forditattac es rendeltettec, az Szenci Molnar Albert által. Kis catechismus, avagy Az keresztyén hütnec részeiröl rövid kérdesekben es feleletekben foglaltatot tudomány, az mint sok tartományokban valo egyházakban es iskolákban szoktác tanitani az együgyöëket es a gyermekeket.Szent irasbéli mondasokkal es imadsagokkal egyetemben szedetöt az haidelbergai öreg catechismusbol. Bp.: Balassi-OSZK, 2017. Hasonmás kiad. 7-54.

VÁSÁRHELYI Judit, P.: A reformáció zsoltárkönyve - Psalterium-kiadások Európában = A reformáció könyvespolca... 72-84. ill.

ZVARA Edina: Scholarly translators and committed disputants. The first century of the Hungarian Bible = Hungarian Studies (32.) 2017. 2. 271-282.

17. század

Koós Balázs: „Szent Biblia, az egész keresztyénségben bé-vött régi deák bötüből. Magyarra fordította. a' Jésus-alatt Vitézkedö Társaság-béli Nagy-Szombati Káldi György pap.” = A reformáció könyvespolca... 85-96. ill.

VÁSÁRHELYI Judit, P.: Ablaß und Gnaden Büchlein..., Wimpaissing an der Leitha, 1601. = Lelkiség és irodalom... 509-516. ill.

Szenci Molnár Albert: Psalterium Ungaricum, Szent David kiralynac es prophetanac szaz ötven soltari az franciai notáknac és verseknec módgyokra most úyonuan magyar versekre forditattac es rendeltettec, az Szenci Molnar Albert által. Kis catechismus, avagy Az keresztyén hütnec részeiröl rövid kérdesekben es feleletekben foglaltatot tudomány, az mint sok tartományokban valo egyházakban es iskolákban szoktác tanitani az együgyöëket es a gyermekeket.Szent irasbéli mondasokkal es imadsagokkal egyetemben szedetöt az haidelbergai öreg catechismusbol. Bp.: Balassi-OSZK, 2017. (526) pag. var. + mell. (54 p.). ill. Hasonmás kiad. (Bibliotheca Hungarica antiqua; 46.)

A mellékletben P. Vásárhelyi Judit tanulmányával.

\section{7-18. század}

BAJÁKI Rita: Az Agonia Christi társulatok imakönyveiről = Barokk vallásos közösségek / szerk. BogÁr Judit, Déri Eszter. Bp.: MTA-PPKE Barokk Irod. és Lelkiség Kutcsop., 2017. 9-17.

BARTóK István: Manuductio ad Eloquentiam,1709. A nagyszombati retorikai kézikönyv mintája és kiadója = ItK (121.) 2017. 6. 816-820.

Bujtás László Zsigmond: Die ungarischen Galeerensklaven-Pediger als Erinnerungsort in den Niederlanden im 17-18. Jahrhundert $=$ Erinnerungsorte im Spannungsfeld unterschiedlicher 
Gedächtnisse: Galeerensklaverei und 1848 / Hrsg. Pál S. VARgA, Karl Katscthaler, Miklós TAKÁCs. Debrecen: Debrecen Univ. Press, 2017. 11-43. ill.

A tanulmány a szerző A pozsonyi vésztörvényszékről és a gályarabságról szóló, magyar szerzőktől származó szövegek sorsa 17-18. századi holland kiadványokban címü dolgozatának jelentősen bővített változata

Doнг Zsuzsánna: Időben születő sorozatkompozíció az emberi „,béke” öt dimenziójában. Pápai Páriz Ferenc Pax-sorozata $=$ Az idő alakzatai és időtapasztalat a magyarságtudományokban. A doktoriskolák V. nemzetközi magyarságtudományi konferenciájának előadásai. Pécs, 2015. augusztus 27-28. / szerk. Bene Sándor, Dobos István. Bp.: Nk. Magyarságtud. Társ., 2017. $145-158$.

PÁLFY Eszter: Egy kiadás távlatai. A Gyöngyösi-recepció sajátosságaiból = Az idő alakzatai és idötapasztalat a magyarságtudományokban. A doktoriskolák V. nemzetközi magyarságtudományi konferenciájának előadásai. Pécs, 2015. augusztus 27-28. / szerk. Bene Sándor, DoBos István. Bp.: Nk. Magyarságtud. Társ., 2017. 133-144.

18. század

ECSEDY Judit, V.: Újabb hamis impresszumú könyvek = Lelkiség és irodalom... 487-490. ill.

KIss László: „,...nyelvünkön még illyetén könyv nem találtatik...”. Marikowzki Márton Néphez való tudósítása 1772-böl = Magyar Orvosi Nyelv (17.) 2017. 2. 65-68. ill.

KURTA József: Egy füstbement terv. Vetsei István Ostervald-fordítása, avagy ki fordította le még Ostervald „Traité des sources de la corruption qui règne aujourd'huy parmi-les chrétiens”címü művét magyarra? = Vallásos kultúra és életmód a Kárpát-medencében 10. Konferencia Veszprémben a Laczkó Dezső Múzeum és a Veszprémi Hittudományi Főiskola közös szervezésében, 2014. május 20-23. / szerk. PiLIPKó Erzsébet, Fogl Krisztián Sándor. Veszprém: Laczkó D. Múz., 2017. 921-925.

MACZÁK Ibolya: Piarista szerzők prédikációi a 18. században $=$ Hitre, tudásra. A piaristák és a magyar művelődés. Budapesti Történeti Múzeum, Vármúzeum, 2017. november 15.-2018. február 25. Kiállítási katalógus 1. Bp.: BTM-Piarista Rend M. Tartománya, 2017. 475-480.

Torda István: A Bácsmegyey ismeretlen első kiadása = MKsz (133.) 2017. 4. 466-472.

A Jelentés (előszó) eddig ismeretlen korábbi, és kibővített, átdolgozott, már ismert változatainak szövegközlésével

18-19. század

NAGY Andor: Eszterházy Károly és a 19. századi egri főpapok könyvkiadási tevékenysége = Karol Eszterházy a vydavatel'ská činnost jágerských prelátov v 19. storoči = Az Esterházyak fraknói ifjabb ága / összeáll. ... STREŠŇÁK Gábor. Szenc: s. n., 2017. 430-445. ill.

A tanulmány bilingvis formában (magyar és szlovák nyelven) jelent meg

19. század

FAZEKAS Csaba: Bihar vármegye állásfoglalásai egy álnéven megjelent könyv ügyében, 1838-1839 = Egyháztört. Szle (18.) 2017. 4. 143-148.

HavAY Viktória: Gaal György népmeséi, avagy mit tudunk a magyar elsőről? = Nyom-követés 2. Tanulmánykötet. A Vajdasági Magyar Doktoranduszok és Kutatók Szervezete és a Doktoranduszok Országos Szövetsége Irodalomtudományi Osztály I. közös konferenciájának tanulmánykötete / szerk. Domokos Gyöngyi et al. Újvidék: Vajdasági M. Doktoranduszok és Kutatók 
Szervezete; Bp.: DOSZ Irodalomtudományi Oszt., 2017. 45-55. (Doktoranduszok Országos Szövetsége Irodalomtudományi Osztály tanulmánykötet; 2.)

RózsAfalvi Zsuzsanna: Eötvös Károly és a Révai Testvérek = Két évforduló között. Eötvös Károly-tanulmányok / szerk. Praznovszky Mihály. Veszprém: Prospektus ny., 2017. 46-57.

SZABÓNÉ KozMA Katalin: Jakob Glatz gyermekkönyveinek magyar fordításai = Fordítás, tolmácsolás, értelmezés... 6-78. ill.

SzETEY Szabolcs: Albertini énekeskönyvének fordítója: Dobos János = Lelkiség és irodalom... 401-404.

Dobos János német nyelvü levelének szövegközlésével és magyar fordításával

\section{9-20. század}

ITTzÉs Nóra: Mákfejgyüjtögetés - Szótárírás Kresznericstől a Nagyszótárig = Vasi Szle (71.) 2017. 2. 143-151.

Elhangzott előadás szerkesztett szövege (Kresznerics Ferenc Könyvtár, Celldömölk, 2016. október 14-15.).

20. század

BiBor Máté János: Kettő az egyben. A Száz vers első kiadásai = Valóságos könyvtár, könyvtári valóság. Könyvtár- és információtudományi tanulmányok 2016 / szerk. KIszL Péter, BoDA Gáborné KöNTÖs Nelli Bp.: ELTE BTK Könyvtár- és Információtud. Int., 2017. 103-109.

\section{Sajtótörténet}

19. század

BARNA Béla: Az Egri Újság indulása és első munkatársai. Modern haladást a „ma pártszempontoktól átszaturált keblekben" = Könyv, kontextus, medialitás. Tanulmányok a 60 éves Széchenyi Ágnes tiszteletére / szerk. BuzinKay Géza, Martin József. Eger: EKE Líceum K., 2017. 27-37.

KIss László: Egy füstbe ment terv. Az első magyar orvosi szakfolyóirat. 250 éve született Sándorffi József = Magyar Orvosi Nyelv (17.) 2017. 1. 25-28.

LuKÁCs Anikó: Jámbor Endre és a Férfidivat-közlöny. Szabászati szaklapok az 1860-as években = Divat, egyén, társadalom. A divattörténeti tudományos konferencia tanulmánykötete / szerk. F. Dózsa Katalin, SzATMÁri Judit Anna, Vér Eszter Virág. Bp.: ELTE Eötvös K., 2016. 111-127.

MÉszÁros Zsolt: A Magyar Bazár és a 19. századi divatlapkutatás új perspektívái = Certamen IV. Előadások a Magyar Tudomány Napján az Erdélyi Múzeum-Egyesület I. Szakosztályában. Nyelv-, irodalom-, néprajztudomány, régészet, történelem, művészettörténet. Kolozsvár: Erdélyi Múzeum-Egyes., 2017. 81-93.

MÉszÁros Zsolt: Női hálózatok és a 19. századi divatlapok. A Magyar Bazár és olvasóközönsége = MKsz (133.) 2017. 3. 297-313.

PÁKozdi Éva Szilvia: A Veszprémi Hírlap és alapítója a sajtó aranykorában és a politika viharaiban = Veszprémi Szle (19.) 2017. 2. 75-86.

Simon Bernadett: „Nagy ünnep lesz ez!”. A Milleniumi Kiállítási Értesíto ígérete = Fordítás, tolmácsolás, értelmezés... 229-242. ill. 
UJVÁRI Hedvig: Identitások és kommunikációs csatornák. Magyar - német - zsidó kulturális metszéspontok a dualizmus kori Magyarországon Bp.: MTA BTK, 2017. 141 p. (Médiatudományi könyvek)

19-20. század

GeLLÉR Ferencné: Dongók és dongó fullánkok. Fejezet a debreceni élclapirodalom történetéböl. 1861-1915, 1953 és 1956. Debrecen: Gellér F.-né, 2017. 146 p. ill.

KLESTENITZ Tibor: A politikai bulvársajtó megjelenése - egy új múfaj a budapesti sajtópiacon = A véleménysajtótól a tömegsajtóig... 127-150.

Lesfalvi Tibor: A dualizmus kori szlovák nyelvü sajtó tevékenységével kapcsolatos sajtóperek és hátterük a XIX. század végén és a XX. század elején = Világkép és etimológia. Írások Nyomárkay István 80. születésnapjára. Az MTA Modern Filológiai Társaság tudományos konferenciájának előadásai. Bp., 2016. június 22. / szerk. NYomÁRKAY István, PAPP Andrea. Bp.: Modern Filológiai Társ., 2017. 219-227.

ORDASI Ágnes: Egy betiltott kisebbségi lap. A fiumei La Difesa története $(1898-1901)=$ Pro Minoritate. 2017. Nyár. 59-85.

A véleménysajtótól a tömegsajtóig. Fejezetek a magyar újságírás történetéből / szerk. KLESTENITZ Tibor, PAÁL Vince. Bp.: MTA BTK, 2017. 182 p. ill. (Médiatudományi könyvek)

20. század

Bartha Ákos: A Nemzeti Radikális Párt (1930-1936) és sajtója = MKsz (133.) 2017. 3. 314-340. A Budapesti Újságírók Egyesülete 1910-ik évi almanachja. Utazás az újságírás körül / szerk. SzerDAHELYI Sándor; kísérő tanulmány SzÉNÁSI Zoltán, VISY Beatrix. Repr. kiad. Bp.: OSZK - Argumentum K., 2017. ill.

Az eredeti kiadás megjelenési adatai: Bp.: Budapesti Újságírók Egyesülete, 1910

HarkaI VASS Éva: Nyugat, 1916 = E nagy tivornyán. Tanulmányok 1916 mikrotörténelméről / szerk. Kappanyos András; szerk. mtársai SARankó Mária, SzénÁsi Zoltán. Bp.: MTA BTK, 2017. 181-185.

HorvÁth Sándor: Pável Ágoston és a gyüjtőhálózat szervezése = Vasi Szle (71.) 2017. 6. 682-688. ill.

A Vasi Szemle történetéhez

ILYEFALVI Emese: Egy írásgyakorlat további kontextusai. Alternatív protestáns folyóiratkultúra a 20. század első harmadában Erdélyben = Aranyhíd. Tanulmányok Keszeg Vilmos tiszteletére / szerk. JAKAB Albert Zsolt, VAJDA András. Kolozsvár: Kriza J. Néprajzi Társ. - BBTE M. Néprajz és Antropológia Int.- Erdélyi Múzeum-Egyes., 2017. 759-777. ill.

Kéziratos egyházi sajtó Erdélyben

KÁLI Csaba: A zalai sajtó a koalíció éveiben, 1945-1947 = A forradalom vonzásában. Tanulmányok Szántó László tiszteletére / szerk. PolgáR Tamás, Récsei Balázs. Kaposvár: MNL Somogy M. Lvt., 2017. 243-252. ill.

KLestenitz Tibor: Bangha Béla jelentése a budapesti nunciusnak a Központi Sajtóvállalat helyzetéröl = MKsz (133.) 2017. 1. 67-80.

Bangha Béla német nyelvü jelentésének szövegközlésével

PAPp Barbara - Sipos Balázs: Modern, diplomás nő a Horthy-korban. Bp.: Napvilág, 2017. 339 p. ill.

Sajtótörténet: 185-267. 270-297. 


\section{Sajtótermékek mint forrásanyagok}

BALOG Beáta: Életreformelemek megjelenése az 1920-1930-as években a Magyar Lányok címü folyóiratban = Továbbélő utópiák. Magyar életreform-törekvések és nemzetközi recepciós hatások / szerk. NéMEth András, VincZe Beatrix. Bp.: Gondolat, 2017. 58-80.

BuCHMÜLler Péter: A kőszegi zsidóság reprezentációja a Kőszeg és Vidéke című hetilapban 1909 és 1939 között = Médiakutató (18.) 2017. 1/2. Fogolymédia. 97-107.

BuDA Attila: Mi történt 1929. október 28-án? Osvát Ernő halála a napisajtó oldalain = Milyen a nyár Amherstben. Esszék, tanulmányok, források Bp.: Ráció, 2017. 305-322.

FónAGY Zoltán: A kiegyezés fogadtatása a sajtóban = MTud (178.) 2017. 12. 1535-1540.

GLÄSSER Norbert: „Égből szállott mireánk ez a korona, Isten küldte azt neked miáltalunk”. IV. Károly koronázásának neológ izraelita diskurzustradíciói = Ethnographia (128.) 2017. 2. 223-238. ill.

Háborús mindennapok, mindennapok háborúja. Magyarország és a Nagy Háború, ahogy a sajtó látta, 1914-1918 / szerk. KABA Eszter. Bp.: Politikatört. Int. - Napvilág, 2017. 427 p. ill.

LANDGRAF Ildikó: Nemzeti érzés és királyhüség. 1848-1849 hőseinek és az uralkodócsalád tagjainak megjelenése a Vasárnapi Ujság lapjain szövegfolklorista szemmel = A véleménysajtótól a tömegsajtóig... 39-57. ill.

MANHERCZ Orsolya: A korona megtalálása 1853-ban. Az esemény bemutatása a kortárs sajtóban = A véleménysajtótól a tömegsajtóig... 23-38.

A tanulmány az esemény magyar - és a magyarországi német nyelvű sajtóbeli megjelenését is tárgyalja

MészÁros Márton: Ravasz vagy Balthazár? Antiszemitizmus-vita a protestáns lapokban 1917-ig = Holokauszt. Új utak, új generációk / szerk. AnTAL Nikolett, MÉsZÁRos Márton. Bp.: FISZ, 2016. 69-82.

MolnÁr László, V.: Az orosz tudományos élet recepciója két hazai folyóiratunkban. A „Magyar Könyv-ház” és a „Sokféle” korabeli híranyaga = Turul (90.) 2017. 1. 46-50.

NAGY Gábor, Sz.: „A politika nem a mi feladatunk”. A Szív politikai állásfoglalásai a koalíciós időszakban = Egyháztört. Szle (18.) 2017. 1. 100-113

RózsA Mária: A prágai Ost und West magyar vonatkozású közleményei. 1837-1848= MKsz (133.) 2017. 3. 283-296.

SoNNEVEND Péter: Könyvtár a „kultúrforradalomban”. A Szabad Nép könyvtárról és olvasásról, 1945-1956 = KF (27.) 2017. 3. 385-401.

TAmÁs Ágnes: Selbstbilder und gegenseitige Stereotype der Slowaken und Ungarn in der zweiten Hälfte des 19. Jahrhundert = Acta Historica Neosoliensia (20.) 2017. 2. 67-86. ill.

TAMÁs Ágnes: Numerus clausus és a „zsidókérdés” karikatúrákon = Iskola, művelődés, társadalom. Az oktatás, nevelés és művelődés társadalomtörténeti látószögei. A Hajnal István Kör - Társadalomtörténeti Egyesület 2015. évi, sárospataki konferenciájának tanulmánykötete / szerk. SAsfi Csaba, Ugrai János. Bp.: Hajnal I. Kör Társadalomtört. Egyes., 2017. 521-533. ill.

TAmÁs Ágnes: Old-new enemies in Hungarian and Yugoslav Caricatures after the Second World War (1945-1947) = Istraživanja (28.) 2017. 171-188. ill.

TAMÁs Ágnes: Karikatúrák a propaganda szolgálatában.1939-1944. = Századok (151.) 2017. 2. 408-442.

TAMÁs Ágnes: Demokraták és a nyugat jugoszláv és magyar karikatúrákon (1945-1947) = Tanulmányok (Univerzitet u Novom Sadu. Filozofski fakultet. Odsek za hungarologiju. Katedra za mađarski jezik i književnost). 2017. 209-223.

TAmÁs Ágnes: Propagandakarikatúrák ellenségképei Szarajevótól Párizsig. Bp.: Kalligram, 2017. 343 p. ill. 
Turbucz Dávid: Piłsudski megítélése Magyarországon a két világháború között $=$ Történelmi Szle (59.) 2017. 1. 145-162.

Turbucz Dávid: A baloldali emigráció sajtójának Horthy-képe az 1920-as évek elején = A véleménysajtótól a tömegsajtóig... 165-182.

UJVÁRI Hedvig: „Vigadó” és „főiskola”. A bécsi (1873) és a párizsi (1878) világkiállítás Max Nordau olvasatában $=$ Könyv, kontextus, medialitás. Tanulmányok a 60 éves Széchenyi Ágnes tiszteletére / szerk. BuzinKay Géza, Martin József. Eger: EKE Líceum K., 2017. 315-327.

VALLASEK Júlia: „Hőst ne csak legendaszerü vértezetben...”. Hadirokkantak megjelenítése az első világháborús magyar sajtóban $=$ E nagy tivornyán. Tanulmányok 1916 mikrotörténelméről / szerk. Kappanyos András; szerk. mtársai Sarankó Mária, SzÉnÁsi Zoltán. Bp.: MTA BTK, 2017. 349-375.

VARGA Csaba: Moór Gyula a napisajtóban = Iustum aequum salutare (13.) 2017. 1. 155-174.

VÖRös Katalin: Az iparoktatás és külföldön. Kísérlet a dualizmus kori pedagógiai sajtó és iparoktatás-politika árnyalására = Századvég 2017. 1. Századforduló. 81-99. ill.

A külföldi iparoktatás szerepének és reprezentációjának vizsgálata a Magyar Iparoktatás 18961904 között megjelent számaiban

\section{Könyvtártörténet}

\section{Több évszázadot érintő munkák}

Schmelczer-PohÁNKa Éva: Die Büchersammlungen der katholischen kirchlichen Hochschulbildung in Fünfkirchen von Anfang bis zum Ende des 18. Jahrhunderts = University and universality... 341-368. ill.

BöszÖRMÉNYI István: „Az egyház szeme fénye az oskola”. A losonci református gimnázium (líceum) története. Komárom: Calvin J. Teológiai Akad., 2016. 546 p. ill.

Könyvtártörténeti fejezettel: Az iskola könyvtára: 52-58.

18-19. század

VERÓK Attila: Magyarországi nemzetek bibliotékái és a Telekiek = A Telekiek és a kultúra... 45-56. 325. 332 .

19. század

LÁszLó Lóránt: Kelemen Márton könyvtáros és Szakáts János segédőr konfliktusa = A Telekiek és a kultúra... 275-289. 331. 338.

19-20. század

KaPRONCZAY Károly: A Semmelweis Orvostörténeti Könyvtár története: 1837-től napjainkig Bp.: Johan Béla Alapítvány: MTEI, 2017. 147 p. (Magyar tudománytörténeti szemle könyvtára; 120.)

20. század

BÁNYAI Réka: „Pufiana”. Eltünt, megkerült, lappangó könyvek = A Telekiek és a kultúra... 291-323. 331. 338 . 
A Függelékben az ügyhöz kapcsolódó iratok, levelezés szövegközlésével és a Teleki Tékából hiányzó RMK-k listájával

PogÁnYné RózSA Gabriella: A budapesti katonai, illetve hadikórházak és könyvtáraik az I. világháború idején = Orvosi Könyvtárak (14.) 2017. 2. 27-38. ill.

\section{Bibliofília, magánkönyvtárak}

DóвÉк Ágnes: Történeti témájú könyvek egy föpapi hagyatékban (1765) = Szóra bírni az újkort. A III. KoraújkorÁSZ doktorandusz konferencia tanulmányai / szerk. BoDNÁR-KIRÁLY Tibor, HENDE Fanni, PATAKI Katalin. Bp.: DOSZ - ELTE BTK Történelemtud. Doktori Isk., 2016. 97-113.

FAZAKAS László: Könyvkultúra a kolozsvári kaszinókban = Korunk (28.) 2017. 1. Változó idők változó társadalom. 75-79.

HoRvÁTH József: Újabb adalékok a 18. századi győri magánkönyvtárak történetéhez. Fekete Imre, Koller Katalin és mások könyveiről = Győri tanulmányok. 2017. 38. 133-145.

KIMPIÁN Annamária: A Teleki Téka disszertációgyüjteménye = A Telekiek és a kultúra... 225-245. 330. 337. ill.

KomorovÁ, Klára: Luther műveinek 16. századi kiadványai a szlovák könyvtárakban és possessoraik = A reformáció könyvespolca... 9-24. ill.

KURTA József: Bod Péter könyvtárának kötetei a Kolozsvári Protestáns Teológiai Intézet könyvtárában = Egyháztört. Szle (18.) 2017. 2. 124-126.

KuRucz György: A racionális gazdálkodás könyvészete az egykori Podmaniczky és Prónay családi könyvtárak állományában = A báró Podmaniczky család szerepe a 18-19. századi magyar kultúrában / szerk. GurKa Dezső. Bp.: Gondolat, 2017. 191-204.

PoGÁnYNÉ Rózsa Gabriella: Magyar királyi honvédségi tiszti magánkönyvtárak a XIX-XX. század fordulóján $=\mathrm{KF}$ (27.) 2017. 4. 549-562.

RÁcz Emese: „Bibliothecam(...) az Enyedi Collegiumnak maradgyon”. Teleki József (1675-1732) könyves mecenatúrája = A Telekiek és a kultúra... 91-112. 326. 333. ill.

SAKToRovÁ, Helena: Reformációs irodalom Thurzó György nádor könyvtárában = A reformáció könyvespolca... 25-33. ill.

VARGA Bernadett: Még egyszer a Todoreszku-Horváth könyvtárról = MűvtörtÉrt.(66.) 2017. 2. 329-350.

\section{Olvasástörténet}

BíRó Csilla: Seneca Christianus a nagyszombati Sarlós Boldogasszony Társulat kiadványai között = Barokk vallásos közösségek / szerk. BoGÁR Judit, DÉRI Eszter. Bp.: MTA-PPKE Barokk Irod. és Lelkiség Kutcsop., 2017. 43-53.

BitsKey István: Egy Kalauz-példány Tápiószelén Lelkiség és irodalom... 103-106. ill. Az RMNy 1293. tétele alatt nyilvántartott 2. kiadás (Pozsony, 1623.) egy példányáról

BoRVÖLGYI Györgyi: Az első református főgondnok egykori könyvespolcáról. Néhány kötet Ráday Pál olvasmányai közül = A reformáció könyvespolca... 117-125. ill.

BudA Attila - TüsKÉs Anna: Horatius, Ovidius és Vergilius művei a fóti Károlyi-kastély egykori és a keszthelyi Festetics-kastély ma is látogatható Helikon könyvtárában = MKsz (133.) 2017. 2. 174-196. ill.

CsORBA Dávid: Adatok Medgyesi Pál peregrinációjához és három könyvéhez = Egyháztört. Szle (18.) 2017. 4. 138-142. 
Czintos Emese: Példától az olvasmányig. A (szép)história a 16. század magyar irodalmában. Bp.: Reciti, 2017. 235 p. (Irodalomtörténeti füzetek; 179.) Olvasmánytörténet, kiadói politika: 71108.

Dомокоs Mariann: Olvasástörténet és folklorisztika. Közelítések a ponyvamesék 19. századi paraszti recepciójához $=$ Iskola, művelődés, társadalom. Az oktatás, nevelés és művelődés társadalomtörténeti látószögei. A Hajnal István Kör - Társadalomtörténeti Egyesület 2015. évi, sárospataki konferenciájának tanulmánykötete / szerk. SASFI Csaba, UGRAI János. Bp.: Hajnal I. Kör Társadalomtört. Egyes., 2017. 463-478.

ÉGER Gábor: Eszéki T. István könyvgyűjteménye a sárospataki Nagykönyvtárban = Diáktudósok. A XXXIII. OTDK 13. Szekciójának első helyezett pályamunkái. Pedagógiai, Pszichológiai, Andragógiai és Könyvtártudományi Szekció / szerk. Szirmai Éva. Szeged: SZEK JGYF K., 2017. 303-318.

EgYed Emese: A zseniális olvasó. Teleki Domokos: A Spanyolok Mexicóba = A Telekiek és a kultúra... 139-158. 328.335.

Teleki Domokos kéziratban maradt drámájának forrásairól.

FARKAS Gábor Farkas: Kopernikusz és az olvasók = A kopernikuszi fordulat fél évezred távlatában / szerk. LAKI János, SzÉKelY László. Bp.: Könyvpont - L’Harmattan, 2016. 95-118.

A tanulmány a szerző A könyv, amelyet senki sem olvasott. Adalékok a heliocentrikus modellröl folytatott vitához. = MTud (176.) 2015. 168-174. címü dolgozatának bővített változata.

Frauhammer Krisztina: Olvasva imádkozni, imádkozva olvasni. Alfabetizáció és olvasástörténeti adalékok az imakönyv müfaja kapcsán = Aranyhíd. Tanulmányok Keszeg Vilmos tiszteletére / szerk. JAKAB Albert Zsolt, VAJDA András. Kolozsvár: Kriza J. Néprajzi Társ. - BBTE M. Néprajz és Antropológia Int. - Erdélyi Múzeum-Egyes., 2017. 705-715.

JÁKI László: Gondolatok az iskolai önképzőkörök könyvtárairól = KKK (26.) 2017. 7. 29-35.

KеCSKEMÉTI Gábor: Zrínyi Miklós és a németországi államelméleti gondolkodás újabb szakasza = Határok fölött. Tanulmányok a költő, katona, államférfi Zrínyi Miklósról / szerk. BENE Sándor et al. Bp.: MTA BTK, 2017. 435-448.

Knapp Éva: Matthaeus Tympius retorikai vonatkozású müvei Magyarországon $=$ MKsz (133.) 2017. 1. 32-54.; = Librum evolvo... 43-66.

LÁzs Sándor: Nyelvhasználat és anyanyelvü irodalom a magyar domonkos reformban. A magyar domonkos apácák olvasmányai = Az első 300 év Magyarországon és Európában. A Domonkos-rend a középkorban / szerk. Csurgai Horváth József. Székesfehérvár: Alba Civitas Tört. Alapítvány, 2017. 207-233.

A Függelékben a magyar reform idején írt domonkos kódexek listája

MARTIS Zsombor: Polemikus olvasói bejegyzés egy Czeglédi-irat szennylapján = Egyháztört. Szle (18.) 2017. 2. 127-133. ill.

Mizera Tamás: Erudíció és neveléstörténet. A kora újkori Felvidék tanítókönyvtárainak vizsgálatáról = Mủvelődéstörténeti kalászatok / szerk. CzEGLÉDI László, MizerA Tamás, VeróK Attila. Eger: EKE Líceum K., 2017. 36-42.

Mizera Tamás: Pillanatkép a kora újkori Felső-Magyarország könyves müvelődéséröl - Váradi György (1630-1682 után) iskolamester és olvasmányai = Tanulmányok Heves és Nógrád megye történetéből / szerk. NemEs Lajos. Eger: Heves M. Honismereti Egyes.; Romhány: Lakóhelyünk Tört. Honismereti Egyes., 2017. 187-204.

Mizera Tamás: A felvidéki bányavárosok mủvelt tanítóinak olvasmányai a 16-17. században = Tavaszi Szél 3. / szerk. Keresztes Gábor Bp.: Doktoranduszok Országos Szövetsége, 2017. $228-232$.

MizerA Tamás: Magánkönyvtár, polgári könyvtár - tanítókönyvtár? A kora újkori Felvidék tanító értelmiségének olvasmánymüveltségéről = Válogatott tanulmányok a pedagógiai elmélet és 
szakmódszertanok köréből / szerk. KARLOVITZ János Tibor. Komárno: International Research Institute, 2017. 9-15.

Monok István: Deutsche Verfasser deutschsprachiger Bücher im Lesestoff von Aristokraten aus Nord-Kroatien in der frühen Neuzeit $=$ Deutsche Sprache und Kultur in Kroatien. Studien zur Geschichte, Presse, Literatur und Theater, sprachlichen Verhältnissen, Wissenschafts-, Kulturund Buchgeschichte, Kulturkontakten und Identitäten / Hrsg. Wynfrid KRIEGLEDER, Andrea SEIDLER, Jozef TANCER. Bremen: Lumière, 2017. 59-92. ill.

MonoK István: Zrínyi Miklós könyvtára és olvasmányai kortárs könyvtári tükörben $=$ Határok fölött. Tanulmányok a költő, katona, államférfi Zrínyi Miklósról / szerk. BENE Sándor et al. Bp.: MTA BTK, 2017. 27-35.

Monok István: Cultural ideals. Changes in patterns of knowledge. From the point of view of reading history = Hungarian Studies (32.) 2017. 2. 251-270.

MonoK István: A kora újkori Kassa német polgárságának olvasmányai = Művelődéstörténeti kalászatok / szerk. Czeglédi László, Mizera Tamás, VeróK Attila. Eger: EKE Líceum K., 2017. 21-35. ill.

MonOK István: Iskolai használatú könyvek a németújvári protestáns iskola könyvtárában 15691634 = Publicationes Universitatis Miskolciensis. Sectio philosophica (21.) 2017. 2. 236-246.

MonoK István: L'aristocratie de Hongrie et de Transylvanie aux XVIIe et XVIIIe siècles et le livre pour tous $=$ Ex oriente amicitia... 115-126. ill.

OLÁH Róbert: „...redux ex oris Hollandicis...” A németalföldi könyves müveltség emlékei a Tiszántúli Református Egyházkerület Nagykönyvtárában = Németalföld emlékei Magyarországon. Magyar - holland kapcsolatok / szerk. BÁrÁNY Attila et al. Debrecen: Debreceni Egy. K., 2017. 109-121. ill.

OLÁH Róbert: Idősebb Geleji Katona István könyvei a Teleki-Bolyai Könyvtárban = A Telekiek és a kultúra... 57-90. 326. 333. ill.

A mellékletben Geleji Katona könyveinek katalógusával

ÖRSI Julianna: Mindenes Gyüjtemények, mint a református deákok ismereteinek tükrei = Iskola, müvelődés, társadalom. Az oktatás, nevelés és müvelődés társadalomtörténeti látószögei. A Hajnal István Kör - Társadalomtörténeti Egyesület 2015. évi, sárospataki konferenciájának tanulmánykötete / szerk. SASFI Csaba, UgraI János. Bp.: Hajnal I. Kör Társadalomtört. Egyes., 2017. 479-489. ill.

Gyárfás István olvasmánymüveltségéröl feljegyzései alapján

Ősz Sándor Előd: Wittenbergben vásárolt Kálvin-kötetekről. Kísérlet a peregrináció-kutatás továbbfejlesztésére = Gerundium (8.) 2017. 1. Reformáció-Különszám. 114-126. ill.

Ösz Sándor Előd: Erasmus Johannis kolozsvári unitárius lelkipásztor könyvtárának Kálvin-köteteiröl = Korunk (28.) 2017. 9. Reformáció - 500. 27-31.

Ösz Sándor Előd: A budapesti könyvtárakban őrzött Kálvin-kötetek = A reformáció könyvespolca... 34-52. ill.

A Budapesten, Esztergomban, Gyöngyösön és Vácon őrzött Kálvin kiadások katalógusa: 45-52.

PogÁNY György: Olvasómozgalmak, olvasói kampányok 1945-1956 között = KF (27.) 2017. 3. 402-415.

PogÁnyné Rózsa Gabriella: Olvasó katonák és könyvtáraik az I. világháborúban $=$ KN (19.) 2017. 3. $32-61$.

Postma, Ferenc: Ein neulich aufgefundenes Büchlein aus der Privatbücherei von Johannes, János Csécsi Sr. ein kleines Exempel aus der grosen Geschichte der Peregrinatio librorum = Egyháztört. Szle (17.) 2016. 3. 96-102.; = MKsz (133.) 2017. 2. 246-250. ill.

A tanulmány a Magyar Könyvszemlében a magyar nyelvü összefoglaló nélkül jelent meg 
Postma, Ferenc: Warum Johannes Gele Debreceni bei Nacht und Nebel aus Franeker verschwunden ist: Die Franeker Inventarliste seiner dort hinterlassenen Bücher und Güter (1661) = Monokgraphia.Tanulmányok Monok István 60. születésnapjára / szerk. NyERGES Judit, Verók Attila, Zvara Edina. Bp.: Kossuth, 2016. 574-585.

A Függelékben más dokumentumok mellett az inventárium szövegközlésével

Postma, Ferenc: Das Testament des verstorbenen ungarischen Studenten Johannes / János N. Szepsi (Franeker, den 28. April 1658) und die erfreuliche Entdeckung von etlichen Büchern aus seinem Nachlass = Sárospataki Füzetek (21.) 2017. 2. 145-166. ill.

Szepsi végrendeletének szövegközlésével, valamint a Sárospataki Református Kollégium Nagykönyvtárába és a marosvásárhelyi Teleki Tékába (Teleki-Bolyai Könyvtár) visszakerült könyveinek katalógusával

TóTHNÉ RADÓ Cecília: Egy 15. századi pécsi prédikátor müveltsége = Per aspera ad astra (4.) 2017. 1/2. 222-229.

TüskÉs Anna: Pauler Tivadar jogi szakkönyvtárának 1872-es katalógusa = Hagyományok és kihívások V. Múlt és jövő. Országos Könyvtárszakmai Nap, 2016. / szerk. SzABó Panna, SzÉKelynÉ TöröK Tünde. Bp.: ELTE Egyetemi Kvtára és Lvtára, 2017. 99-109. ill.

VERÓK Attila: Der Bibliotheksbestandskatalog als historische Quelle für die Ideengeschichte? $=$ Ex oriente amicitia... 43-62.

VERÓK Attila: Dobra húzott huszita emberbőr? A könyvtörténész megjegyzése egy Husz-követő legendájának margójára = Husz János és a huszitizmus... 127-135.

\section{A múlt neves könyvtárosai, bibliográfusai, újságírói}

BALÁzs Imre József: „Ájult cafat a ma”. Reiter Róbert a Kassák-folyóiratok vonzáskörében = E nagy tivornyán. Tanulmányok 1916 mikrotörténelméröl / szerk. KAPPANYos András; szerk. mtársai SARAnKó Mária, SzénÁsi Zoltán. Bp.: MTA BTK, 2017. 389-396.

BodA Miklós: „Mecsekszabolcsról indult”. A Pontificia Universitas Gregoriana bibliográfusa, Arató Pál S. J. (1914-1993) az egyháztörténeti tudományosság szolgálatában= Lelkiség és irodalom... 107-114. ill.

DÁrdai Ágnes, F.: Fitz József és Domanovszky Ákos, az Erzsébet Tudományegyetem Könyvtárának reformer igazgatói, 1930-1942= KKK (26.) 2017. 12. 24-37.

DÁrdai Ágnes, F.: József Fitz und Ákos Domanovszky. Die Reformer-Direktoren der Bibliothek der Elisabeth-Universität in Pécs (1930-1942) = University and universality... 369-391.

A konferenciaelőadás magyar nyelven megjelent a Könyv, könyvtár, könyvtáros, 2017/12. számában

DEÁK Ágnes: „mint toronyból a bakter”. Arany János folyóiratai „nemzeti és társadalmi kérdések” erőterében $=$ „Hazám tudósi, könyvet nagy nevének!”. Arany János pályájának művelődéstörténeti olvasatai / szerk. CIEGER András. Bp.: Universitas - OSZK - MTA BTK, 2017. 153-194.

GyuRẢCz Ferenc: Pável Ágoston tudományszervezői tevékenysége a Vasi Szemlében = Vasi Szle (71.) 2017. 4. 429-434. 507. 510. ill.

KIsZl Péter - PАткÓSNÉ TóTH Zsuzsanna: „Könyvtárosnak való vagyok, ez érdekel engem”. Walleshausen Gyula, 1923-2010 KF (27.) 2017. 1. 68-83.

A „Ha egy könyvtáros holnap is csak azt teszi, amit tegnap csinált, előbb-utóbb elenyészik, elpusztul az állománya...” c. Walleshausen Gyulával készült interjú közlésével.

Kiszl Péter - PAткósnÉ Tóth Zsuzsanna: „Harmonikus egységbe olvad itt a józan gyakorlatiasság, az elmélet, a tudományos kutatás és a mások kutatásának a támogatása”. Csapodi Csaba (19102004) és Csapodiné Gárdonyi Klára (1911-1993) = KF (27.) 2017. 2. 232-250. ill. 
A „Ha valami nehézség, fennakadás van kutatásainkban, rögtön tanácsot kérhetünk egymástól” c., Csapodi Csabával és Csapodiné Gárdonyi Klárával készült interjú közlésével.

Kiszl Péter - PATKósné TóTH Zsuzsanna: „Tudatosan vállalta a könyvtárosságot, s évtizedeken keresztül hüséggel szolgálta választott hivatását egyetlen munkahelyén, a Budapesti Egyetemi Könyvtárban”. Vértesy Miklós, 1907-1991 = KF (27.) 2017. 4. 563-573.

Vértesy Miklós „....arra a helyre kerültem, ami a szívemnek a legkedvesebb lett, a Ritkaságtárba" címü öninterjújának közlésével

MANN Miklós: A Századok müködése Szilágyi Sándor szerkesztői időszakában (1875-1899) = Századok. (151.) 2017. 1. 11-16.

NAGY Imre: Várkonyi Nándor. Portré és tabló. Pécs: Pro Pannonia, 2017. 333 p. ill. (Pannónia könyvek). (Irodalmunk forrásai) Várkonyi Nándor, mint lapszerkesztő: Várkonyi Nándor és a Sorsunk 267-310.

PAÁL Vince: Újságíróból politikus. Gratz Gusztáv útja a parlamenti tudósítói padból a miniszteri bársonyszékbe $=$ A véleménysajtótól a tömegsajtóig... 79-109.

Rózsa Dávid - Rózsa Gábor: A bibliológia Rózsa György munkásságában = MKsz (133.) 2017. 3. 360-366.

SAs Péter: Kós Károly. Bp.: MMA, 2017. 272 p. ill.

Kós Károly kiadói, szerkesztői és a könyvművészet területén végzett munkásságával 